Ah. 0.2007 .211
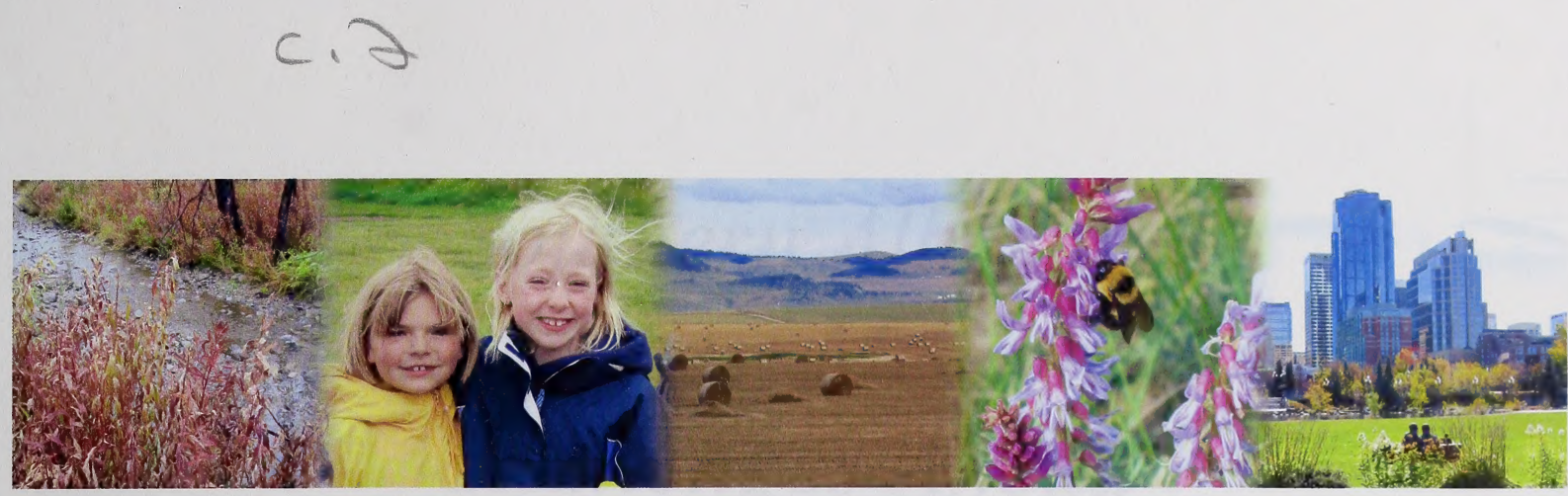

Southern Alberta Landscapes MEETING THE CHALLENGES AHEAD 〉

\title{
Regional Economic \\ Overview and Outlook for Southern Alberta
}

\author{
Prepared for \\ Alberta Environment \\ By R.A. Malatest \& Associates Ltd. \\ April 2005
}


Digitized by the Internet Archive in 2016 


\section{Southern Alberta Landscapes: Meeting the Challenges Ahead}

\section{Regional Economic Overview and Outlook for Southern Alberta}

Prepared for

Alberta Environment

By R.A. Malatest \& Associates Ltd.

April 2005

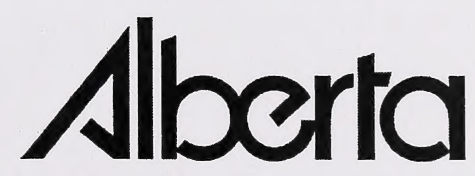




\section{Southern Alberta}

Landscapes: Meeting the

Challenges Ahead

\section{Regional Economic \\ Overview and Outlook for Southern Alberta}


ISBN: 978-0-7785-6315-0 (Print version)

ISBN: 978-0-7785-6316-7 (On-line version)

Website: www.gov.ab.ca/env/

Disclaimer: The contents of this document have been prepared with funds from Alberta Environment but do not necessarily reflect the Ministry's views or policies. Any mention of trade names or commercial products does not constitute an endorsement or recommendation for use.

Any comments, questions or suggestions on the content of this document may be directed to:

Regional Environmental Management

Alberta Environment

3rd Floor, Deerfoot Square

2938 - 11 Street N. E.

Calgary, Alberta T2E 7L7

Ph: (403) 297-7602

Fx: (403) 297-6069

Additional print copies of this document are available from:

Information Centre

Alberta Environment

Main Floor, Oxbridge Place

9820-106 Street

Edmonton, Alberta T5K 2J6

$\mathrm{Ph}:(780)$ 427-2700

Fx: (780) 422-4086

Outside of Edmonton dial 310-0000 for toll-free connection

Email: env.infocent@gov.ab.ca

Copyright in this publication, regardless of format, belongs to Her Majesty the Queen in right of the Province of Alberta. Reproduction of this publication, in whole or in part, regardless of purpose, requires the prior written permission of Alberta Environment.

(C) Her Majesty the Queen in right of the Province of Alberta, 2007 


\section{TABLE OF CONTENTS}

ACKNOWLEDGEMENTS I

EXECUTIVE SUMMARY II

SECTION 1: INTRODUCTION AND BACKGROUND TO THE REPORT ...........1

1.1 THE SOUTHERN AlbERTA LANDSCAPES: MEETING THE CHALlENGES

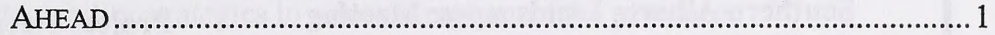

1.2 PURPOSE AND OBJECTIVES OF THIS REPORT ...................................... 2

SECTION 2: PROFILE AND SUMMARY OF THE ECONOMY ...............................3

$2.1 \quad$ ENERGY SECTOR.............................................................................

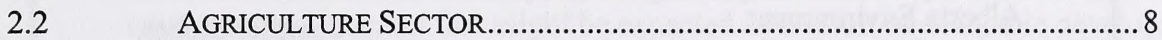

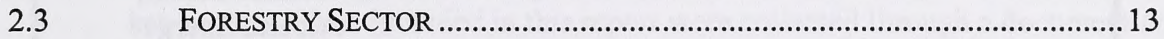

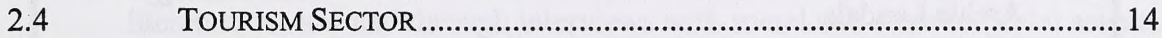

$2.5 \quad$ MANUFACTURING SECTOR................................................................ 16

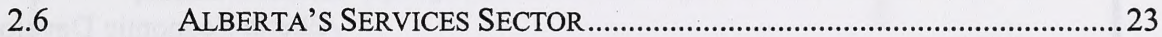

SECTION 3: REGIONAL ECONOMIC CHARACTERISTICS AND TRENDS..27

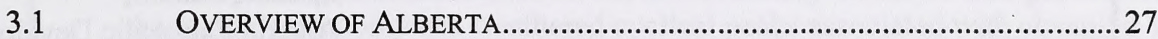

3.2 ECONOMIC OUTLOOK FOR SOUTHERN ALBERTA......................................28

3.3 CALGARY ECONOMIC REGION …………………………………….......30

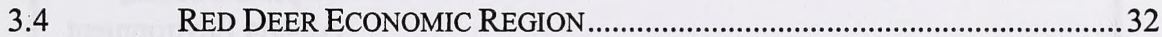

3.5 LETHBRIDGE-MEDICINE HAT ECONOMIC REGION .....................................32

3.6 CAMROSE-DRUMHELLER ECONOMIC REGION ……....................................33

3.7 BANFF-JASPER-ROCKY MOUNTAIN HOUSE ECONOMIC REGION ................34

SECTION 4: CHALLENGES AND BARRIERS TO ECONOMIC GROWTH.....35

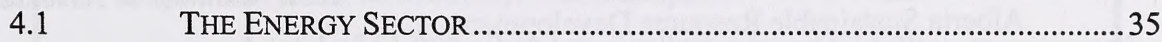

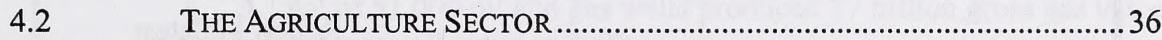

$4.3 \quad$ THE FORESTRY SECTOR..................................................................... 37

$4.4 \quad$ THE TOURISM SECTOR ………………………………………..........

4.5 THE MANUFACTURING SECTOR …………………................................... 39

4.6 THE SERVICES SECTOR .............................................................................. 40

SECTION 5: IMPACTS OF ECONOMIC GROWTH ON THE NATURAL ENVIRONMENT AND QUALITY OF LIFE .......................................41

5.1 IMPACTS OF GROWTH ON THE NATURAL ENVIRONMENT ………………....4 41

5.2 IMPACTS OF GROWTH ON QUALITY OF LIFE ..........................................4 44

5.3 MANAGEMENT OF COMPETING INTERESTS …………………………......4 46

5.4 MANAGING IMPACTS OF HUMAN ACTIVITY ON THE ENVIRONMENT.........46

APPENDIX A: RESEARCH METHODOLOGY AND RESEARCH CONSIDERATIONS APPENDIX B: BIBLIOGRAPHY

APPENDIX C: BACKGROUND AND HISTORICAL ISSUES

APPENDIX D: FORECAST DATA 


\section{ACKNOWLEDGEMENTS}

The Regional Economic Overview and Outlook for Southern Alberta was prepared for Alberta Environment and was funded by Alberta Energy. This report was made possible by the following:

Southern Alberta Landscapes: Meeting the Challenges Ahead Steering

Committee:

Ian Dyson, Chair

Alberta Environment

Archie Landals,

Alberta Community Development

Bill Dolan,

Parks Canada

Bill Symonds

Alberta Municipal Affairs

Brent Paterson,

Alberta Agriculture, Food and Rural

Development

Dom Ruggieri,

Alberta Sustainable Resource Development

Dug Major,

Alberta Municipal Affairs, Special Areas

James Norris,

Alberta Aboriginal Affairs \& Northern

Development

Jennifer Steber,

Alberta Energy

Holly Mayer,

Agriculture and Agri-Food Canada - PFRA

Loren Winnick,

Alberta Economic Development

Pauline Erickson,

Environment Canada
Project Steering Committee:

Jan Simonson, Chair

Alberta Environment

Jennifer Steber,

Alberta Energy

Loren Winnick,

Alberta Economic Development

Michael Sambir,

Alberta Economic Development

Stephen Dobson,

Alberta Environment

\section{Research Consultant:}

R.A. Malatest \& Associates Ltd.:

Robert Malatest

Stephanie Phare

Jordan Bennett

Chris Boughton

In addition, we would like to acknowledge the generous time and support of the key stakeholders who participated in this study. 


\section{EXECUTIVE SUMMARY}

In 1999, the Government of Alberta made the Commitment to Sustainable Resources and Environmental Management policy, which states "Alberta, a member of the global community, is a leader in sustainable development, ensuring a healthy environment, a healthy economy, and a high quality of life in the present and future." In order to help achieve these objectives, Alberta Environment is leading the development of sustainability strategies in selected regions of the province.

This report was compiled to describe the overall sectoral characteristics and trends in economic activity in southern Alberta, to identify key drivers that may determine the future direction of the economy, and to give a general description of the types of environmental impacts that might be expected as a result of economic development in key sectors. Data included in this report were collected through a document and literature review and through interviews with social and environmental scientists, economists, industry representatives, and government officials.

Historically, economic growth and development in southern Alberta were based primarily on agricultural activities, but more recently on the oil and gas sector. Although the region's economy has weathered cyclical peaks associated with changing world energy prices, the recent trend of higher energy prices has provided considerable economic stimulus.

The economic performance of southern Alberta has been among the strongest in Canada. The combination of rising energy prices and the growth of the service economy has stimulated significant residential and non-residential investment throughout the region. A number of sectors, such as energy, agriculture, tourism and manufacturing, play an important role in its economy. For example:

- A total of 51,000 oil and gas wells produced $\$ 7$ billion gross gas value and $\$ 2$ billion gross oil value in 2002 ;

- More than 25,500 farms are located in southern Alberta of which more than one half $(16,071)$ are cattle/livestock farms; total agricultural sales in 2001 were $\$ 10.4$ billion, or $73 \%$ of Alberta sales;

- Tourism brings in excess of $\$ 2$ billion per year to the southern Alberta region annually; and

- The manufacturing sector contributes $\$ 5.4$ billion each year to the Calgary area alone.

The City of Calgary has a population of almost one million people and forms the largest metropolitan area in the province. The city is southern Alberta's major economic hub with almost $70 \%$ of the region's major project spending. Calgary has witnessed real economic growth in excess of $25 \%$ during the second half of the last decade and 125,000 jobs were added between 1996 and 2000, equating to an average annual employment growth rate of $5 \%$. The city is expected to surpass the province in percent change in gross domestic product (GDP), employment, and population between 2002-2006. Growth is also anticipated for smaller neighbouring cities due to their proximity to 
Calgary. For example, Airdrie's population is expected to increase from 19,852 in 2001 to 65,852 by 2031 .

Above average economic growth in the region has not been limited to the Calgary region, as most regions in southern Alberta have realized considerable economic expansion. For example:

- The Lethbridge-Medicine Hat Economic Region had the highest labour force growth rate in Alberta over 2003;

- At 4.1\%, the Camrose-Drumheller Economic Region had the lowest unemployment rate in the province in 2003; and

- In 2003, the Red Deer Economic Region had a 4.0\% labour force growth, largely due to retail centre development.

While southern Alberta has witnessed strong economic growth during the past ten years, it is expected that this rapid rate of growth will begin to abate somewhat during the next five to ten years, reflecting a projected decline in world energy prices as well as the gradual improvement in the economies of other Canadian provinces - which is expected to slow net in-migration to the region.

Notwithstanding the fact that economic activity in the region will likely return to more sustainable levels, the region has a strong economic foundation that will likely contribute to above-average economic growth during the next ten to twenty years. Among these include:

- Considerable proven and potential energy reserves - including coal, oil and gas, as well as potential new reserves including natural gas in coal (coal bed methane) and other renewable energy sources such as wind and biomass;

- An expanding agricultural sector based on traditional operations (livestock, grains) as well as new crops including improved pulses and medicinal plants;

- An extensive and world-renowned tourism sector, anchored by the Calgary Stampede (which draws in excess of one million visitors annually and generates $\$ 240$ million in visitor spending) as well as extensive infrastructure that supports a diverse range of recreational and cultural activities; and

- A growing service sector that supports commercial and head office activity predominantly centred in the Calgary region. Calgary is home to more than 50 head offices of Canada's top 500 companies and all of Canada's major banks maintain their western head offices in Calgary.

Based on the literature reviewed and the information gathered during interviews, key challenges and opportunities for industries in southern Alberta include the following:

- Competition for land between industries such as agriculture, oil and gas, and tourism/recreation is likely to increase in the future;

- Skilled labour shortages and competition for labour, particularly between rural and urban areas and between industries, is a growing concern;

- Maintaining an efficient transportation system is considered to be a high priority in maintaining southern Alberta's access to export markets and long-term economic viability; 
- International trade issues, such as Bovine Spongiform Encephalopathy (BSE) and the softwood lumber dispute, continue to be an issue for several industries in the region; and

- The Kyoto Protocol could have significant ramifications for energy-intensive industries in the region including oil and gas extraction as well as petrochemical and refining industries.

Increased growth could have a number of positive and negative impacts to the natural environment and to quality of life. The literature review and key informants provided several examples of potential impacts, which include the following:

- The supply of water from the South Saskatchewan River Basin available for Alberta may be inadequate, at least in drier years, to meet existing and future demand, and there is evidence that the aquatic environment in parts of the basin has been adversely affected by water diversions;

- Farmland is being lost over time as urban areas expand. This effect is balanced, however, with agricultural expansion in rural areas and increases in farmland productivity. Urban expansion also results in increasing conflicts between urban and rural lifestyles;

- Development in urban areas will negatively affect air quality, noise, and traffic congestion but will positively affect infrastructure and access to health care; and

- Growth in the economy and in population will increase the demand for housing stocks, affordable housing in particular.

Competition for resources, such as that currently seen between industries such oil and gas, agriculture, and forestry for both land and water, is expected to extend and potentially increase into the future. During interviews with key informants, it was asked how competing interests could be best managed. Responses from informants included the following:

- Communication should be collaborative, involve all affected parties, and include industry;

- Planning should focus on long-term goals and outcomes; and

- Environmental policies should be dynamic and evolve over time, and need to be more fully integrated among disciplines and jurisdictions. 


\section{SECTION 1: INTRODUCTION AND BACKGROUND TO THE REPORT}

In order to promote sustainable development and a high-quality environment, Alberta Environment is working with other government departments to develop regional strategies that will "provide direction for natural resource and environmental management for large areas of the province." 1 These regional strategies aim to provide an overview of the region's current situation; assess the interaction between people, the environment and the economy; and forecast potential impacts for the next two generations ${ }^{2}$. Ultimately, this process will provide a means for collaborative planning between the province, stakeholders, and Albertans.

\subsection{The Southern Alberta Landscapes: Meeting the Challenges Ahead}

The Southern Alberta Landscapes: Meeting the Challenges Ahead (SAL) is overseen by a multi-departmental Steering Committee comprised of provincial and federal government staff. The SAL region is comprised of the area outlined in Figure 1-1 below. Although the SAL region is approximately one-fifth $(21.5 \%)$ of the total land area of the province, it encompasses half $(50.1 \%)$ of the province's population, $81 \%$ of which live in urban areas $^{3}$.

Development of the Southern Alberta Landscapes: Meeting the Challenges Ahead will provide a means for collaborative planning between the province, stakeholders and
Figure 1-1 The SAL Region

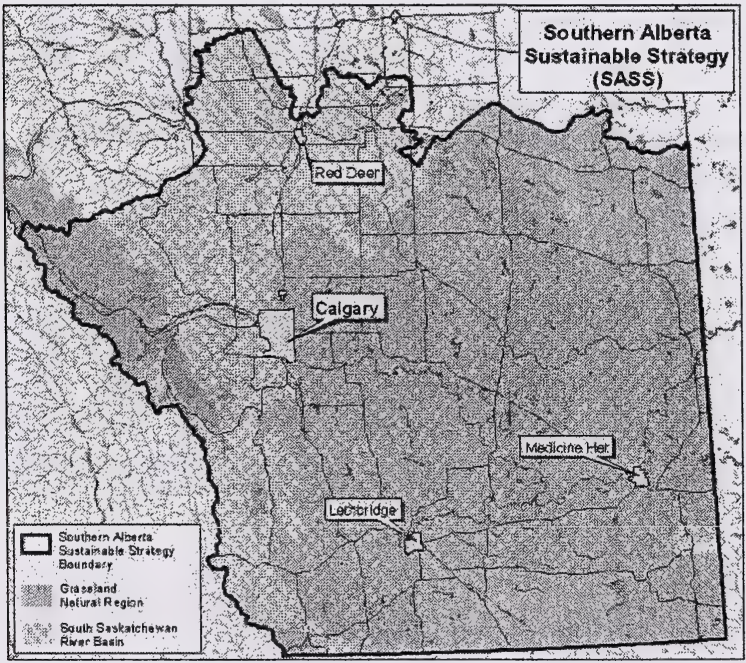

Source: Alberta Environment

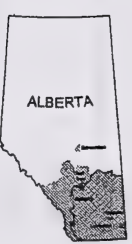

\footnotetext{
${ }^{1}$ Alberta Environment Website. http://www3.gov.ab.ca/env/irm/strategies facts.html. (14 Jul 2004)

${ }^{2}$ Alberta Environment Website. . http://www3.gov.ab.ca/env/irm/strategies facts.html. (14 Jul 2004)

${ }^{3}$ Global Training, Inc. Southern Alberta Landscapes: Meeting the Challenges Ahead: Social/Economic Aspects. Edmonton: Unpublished Report Prepared for Alberta Environment, 2004.
} 
The key objective of SAL is to "involve Albertans in developing a vision of the future of southern Alberta and the desired environmental, social and economic benefits for the region, and then address the issues and follow a plan to achieve the vision." 4 The Southern Alberta Landscapes: Meeting the Challenges Ahead has two phases. The first phase -- Defining the Agenda -- will appraise the current state of the region, identify a vision, goals, and principles for sustainable development, make policy recommendations and identify the key issues that need to be addressed and in what order of priority. The second phase will consist of implementing the policy recommendations, and will be undertaken following the review of the phase one report by various stakeholders, including the provincial government.

Further information about SAL can be accessed by visiting the website http://www3.gov.ab.ca/env/regions/southern/strategy.html.

\subsection{Purpose and Objectives of this Report}

The purpose of this report is to profile the economy of the SAL region, with emphasis on the key relationships between economic development and the natural environment. The final report will be one of several tools used by the SAL Steering Committee to assist in assessing probable future environmental impacts and guiding the formation of policy recommendations to address the impacts.

Specifically, the objectives of the project include the following:

$>$ Describe the overall and sectoral trends in the southern Alberta economy;

$>$ Provide insights into sub-regional aspects of the economy and identify key economic drivers; and

$>$ Describe key relationships between the economy, the natural environments and quality of life factors.

In order to meet these objectives, the Consultant undertook the following research activities:

$>$ A comprehensive literature and statistical review;

$>31$ interviews with key informants; and

$>$ Analysis and reporting.

Appendix A contains information about the methodology used for this report.

\footnotetext{
${ }^{4}$ Southern Alberta Sustainability website. http://www3.gov.ab.ca/env/regions/southern/strategy.html\#SAL (14 Jul 2004)
} 


\section{SECTION 2: PROFILE AND SUMMARY OF THE ECONOMY}

Southern Alberta contains of a variety of climatic regimes and topographical features, which contribute to the unique economic characteristics and trends that are found across the region. There are several sectors that play an important role in the economy of Southern Alberta. These sectors include energy, forestry, tourism, manufacturing, and services and are described in the following sections.

\subsection{Energy Sector}

In 2002, there were 51,000 wells in southern Alberta, producing $\$ 7$ billion gross gas value, and $\$ 2$ billion gross oil value.

\subsubsection{Industry Overview}

Alberta is one of the world's top energy producers, with significant oil, oil sands, natural gas, and coal reserves. Alberta has become the world's fourth largest producer of natural gas and the world leader in oil sands development. The oil and gas industries alone directly or indirectly employed 275,000 people in 2003 , accounted for $22 \%$ of Alberta's Gross Domestic Product (GDP), and 33\% of its provincial budget revenue. The province owns $81 \%$ of Alberta's mineral rights, generating land lease bonuses, rental payments, and royalties worth over $\$ 10$ billion per year. Alberta's gross revenues from all hydrocarbons were $\$ 55.5$ billion in 2003 , with natural gas accounting for more than half the total. ${ }^{5}$

\section{Conventional Oil and Gas}

In 2002 , there were 51,000 wells in southern Alberta, producing $\$ 7$ billion gross gas value, and $\$ 2$ billion gross oil value. Southern Alberta had 184 sweet gas plants, 124 sour gas plants, approximately $117,000 \mathrm{~km}$ of pipelines, and one oil refinery. ${ }^{6}$

In Alberta, the oil and gas extraction industry employed about 51,000 people in 2003. Employment growth in this industry is expected to be about $1.8 \%$ annually from 2003 to 2008. An additional 44,000 people provided support services for the oil and gas extraction and mining industries. Employment growth in the support services sector is expected to be approximately $2 \%$ each year from 2003 to $2008 .{ }^{7}$

\section{Natural Gas in Coal (Coalbed Methane)}

According to the Alberta Energy and Utilities Board (EUB), natural gas in coal (NGC) is in its early stages of development. It is known that large amounts of NGC exist in Alberta, covering virtually the entire SAL region. Production is feasible, but more research is needed to accurately assess the recoverable proportion and what its contribution to Alberta's natural gas supply may be. A cross-ministry review and external consultation process began in 2002 to address concerns about NGC development and to determine if changes to policies and regulations are required for the development of this resource. ${ }^{8}$ Coal zones with NGC potential are shown in Figure 2-1.

\footnotetext{
${ }^{5}$ Alberta Advantage Website. http://www.alberta-canada.com/economy/expdoll.cfm (Accessed 12/02/04)

${ }^{6}$ Alberta Department of Energy PowerPoint Draft Presentation. 2003. SARS Sector Overview

${ }^{7}$ AHRE. http://www.alis.gov.ab.ca/occinfo/IndustryDescriptions/oilgas.html (18 Jan 2005).

${ }_{8}^{8}$ Alberta Energy and Utilities Board. http://www.eub.gov.ab.ca/BBS/public/EnerFAQs/EnerFAQs10.htm (Accessed 11/23/04)
} 
Figure 2-1

Natural Gas in Coal (Coalbed Methane)

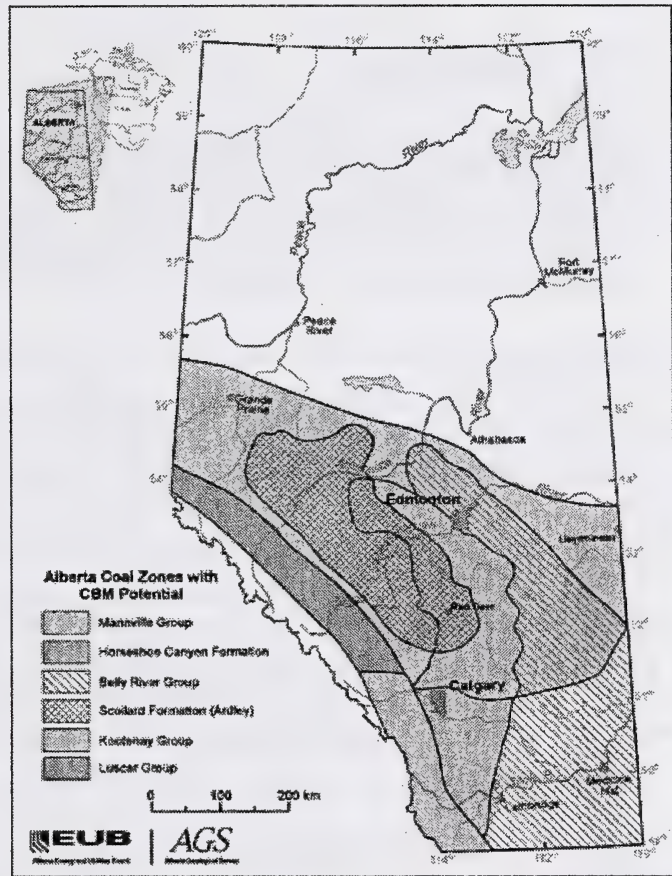

Source: Alberta Energy and Utilities Board Website.

http://www.eub.gov.ab.ca/BBS/public/EnerFAOs/EnerFAOs10.htm

\section{Electricity and Coal}

Most electricity in Alberta is generated through coal-fired plants, but an increasing number of generation plants are fuelled by natural gas. In addition, some electricity is generated by hydroelectric plants and wind-powered plants. Wind power has some of the greatest long-term potential for the energy sector in the SAL region, as the south western regions of the province has ideal conditions for the generation of electricity from this renewable resource. Deregulation of the electric industry occurred on January 1,2001 . Power is now freely traded through an exchange operated by the independent Alberta Electric System Operator (AESO). ${ }^{9}$

Southern Alberta's Sheerness coalmine, located $20 \mathrm{~km}$ southeast of Hanna, produces four million tonnes per year. The Sheerness Mine is a conventional surface strip mining operation. The coal is marketed to ATCO/TransAlta for the Sheerness power plant's production of 760 megawatts (MW) of electricity. Southern Alberta is also home to one gas fired utility, four gas fired non-utilities, and numerous major wind power generation projects. ${ }^{10}$ Between 1998 and 2003 there were numerous operators adding capacity within the SAL region. The largest include a natural gas facility in Calgary with an installed capacity of $300 \mathrm{MW}$ of electricity, and a cogeneration facility in Joffre near Red Deer with a capacity of generating $416 \mathrm{MW}$ of electricity. ${ }^{11}$

\footnotetext{
${ }_{9}^{9}$ Alberta Energy and Utilities Board. http://www.eub.gov.ab.ca/BBS/public/EnerFAQs/EnerFaqs7.htm\#1

${ }^{10}$ Alberta Department of Energy PowerPoint Draft Presentation. 2003. SARS Sector Overview

${ }^{11}$ Alberta Energy. http://www.energy.gov.ab.ca/com/Electricity/Key+Numbers/Key+Numbers.htm (18 Jan 2005).
} 
Since 1980, energy demand in Canada has grown by $29 \%$, and global energy consumption increased 10\% between 1990 and 1999.
High energy prices have contributed to the recent strength in the Canadian dollar.
Notwithstanding the expansion of generation capacity in both traditional and nontraditional sources, the region is still reliant on electricity that is generated outside of the region.

\subsubsection{Industry Trends}

With $68 \%$ of Canada's conventional oil reserves, $83 \%$ of its natural gas reserves and $100 \%$ of its oil sands, the future prospects for Alberta's energy sector are good. Alberta currently produces about $43 \%$ of Canada's conventional crude oil, $80 \%$ of its marketable natural gas, $87 \%$ of its liquefied petroleum gases, $45 \%$ of its coal, and all of its bitumen and synthetic crude oil. ${ }^{12}$

\section{Trade Factors}

Since 1980, energy demand in Canada has grown by $29 \%$, and global energy consumption increased 10\% between 1990 and 1999. The U.S. Energy Information Administration predicts a $60 \%$ increase in global energy consumption between 1999 and 2020. Indications are that the overall long-term trend is for increased prices, but price volatility in oil, natural gas, and electricity will likely remain. Future world prices will depend on a number of factors, including increases in world demand, technological advances, development of new sources of supply, and political instability in oil producing countries. The latter point is emphasized by desire in the U.S. to find more stable sources of hydrocarbons due to recent events in many of the world's oil rich regions. The U.S. market is already the major destination for Alberta's energy exports, receiving $99.8 \%$ of international shipments in 2003 , worth approximately $\$ 40$ billion. $^{13}$

High energy prices have contributed to the recent strength in the Canadian dollar. A higher dollar reduces provincial royalties from oil and gas, which are priced in U.S. dollars. For each one-cent increase in the Canadian dollar, the Alberta government's revenues fall by approximately $\$ 110$ million. $^{14}$

\section{Technology}

General trends in technology include advances in industry best practices such as changes in seismic and drilling technology and practices, reduced flaring and venting emissions, reductions in the use of fresh water in production, and integrated landscape management. Low impact seismic techniques minimize environmental effects by reducing ground disturbance, varying the path of equipment through the forest, and using existing natural trails and narrow cut-lines. Directional or horizontal drilling can reduce the impact of drilling, or reduce the number of individual well sites by drilling multiple horizontal wells from one pad. Industrial best practices include increased use of temporary winter roads, remote monitoring and maintenance of wells, coordinated planning and shared corridors, reduced size of clearings, reduced number of well sites, and reforestation of sites and access routes. Integrated landscape management aims to coordinate resource development to create the smallest "footprint" possible on the land while generating economic efficiencies and cost savings for industry partners. ${ }^{15}$

\footnotetext{
${ }^{12}$ Alberta Department of Energy PowerPoint Draft Presentation. 2003. SARS Sector Overview

${ }^{13}$ Western Centre for Economic Research. 2004. "Alberta's and western Canada's exports: 15 years of free trade agreements." Information bulletin \#80.

${ }_{15}^{14}$ Alberta Government. Economic Update. October, 2004.

${ }^{15}$ Alberta Department of Energy PowerPoint Presentation. SARS Sector Overview. 2003. (17 Nov. 2004)
} 
Conventional oil production has been declining over the past few decades, with royalties falling from $\$ 2.9$ billion in $1984 / 85$ to less than $\$ 1$ billion in 2003/04.
Major energy projects under construction within the $S A L$ region include the $\$ 130$ million Countess Gas storage facility near Hussar to be completed in 2005, and a $345 \mathrm{MW}$, $\$ 300$ million gasfired power plant near Crossfield scheduled for completion in 2006.

\section{Economic Performance}

Conventional oil production is increasingly being replaced by higher cost production from oil sands, which lie outside of the southern Alberta region. Conventional oil production has been declining over the past few decades, with royalties falling from $\$ 2.9$ billion in $1984 / 85$ to less than $\$ 1$ billion in 2003/04. Currently, natural gas prices are of greater importance to Alberta government revenues than conventional oil. In $2003 / 04$, natural gas royalties for the provincial government accounted for $71 \%$ of total non-renewable resource revenues, while conventional oil royalties accounted for $13 \%$. In 2002/03, Alberta's natural gas production supplied approximately $20 \%$ of North America's total natural gas requirements. ${ }^{16}$

The EUB estimates a $70 \%$ increase in total oil production, and a tripling of bitumen production by 2010 . Production of bitumen, which comes primarily from oil sands not located within the SAL region, will account for as much as $70 \%$ of Alberta's oil supply. The EUB estimates about 10,000 successful gas wells will be drilled annually until 2010. By 2010, Alberta's natural gas demand will represent $33 \%$ of production, despite forecasted production declines of $2 \%$ per year between 2005 and 2010 . $^{17}$

In addition to considerable exports of oil and natural gas, the region also produces a considerable volume of coal that is destined for international markets. World demand for coal is expected to increase, especially as the demands of China for metallurgical and thermal coal is expected to continue to support high prices for coal products.

\section{Trigger Points that Stimulate Investment}

High oil prices pose a downside risk to the global economy by reducing the purchasing power of international oil consumers. This dampens exports and consumer spending. However, higher oil prices stimulate investment and production in the Canadian energy sector, which positively affects growth. ${ }^{18}$

The projected high prices for energy resources have, and will likely continue, to provide the foundation for considerable investment in the region's oil and gas sector.

Investment in the sector encompasses a range of activities including:

- Exploration activity with considerable demand for oil and gas services;

- Expansion/upgrading of existing production; and

- Investment in transmission and pipeline systems storage.

\subsubsection{Major Projects}

Major energy projects under construction within the SAL region include the $\$ 130$ million Countess Gas storage facility near Hussar to be completed in 2005, and a 345 MW, $\$ 300$ million gas-fired power plant near Crossfield scheduled for completion in 2006. ${ }^{19}$

A presentation for the Alberta Electric System Operator (AESO) Southwestern Alberta Transmission Development Plan stakeholder meeting in October, 2003 listed existing and committed generation potential in the area at $251 \mathrm{MW}$ of electricity, with a further

\footnotetext{
${ }^{16}$ Alberta Government. Economic Update. October, 2004.

${ }_{17}^{17}$ Alberta Energy and Utilities Board Website http://www.eub.gov.ab.ca/bbs/energystats/default.htm (Accessed 11/17/04)

${ }_{18}$ Alberta Department of Energy PowerPoint Draft Presentation. 2003. SARS Sector Overview

${ }^{19}$ Alberta Finance. "Budget 2004: Economic Outlook."
} 
proposed capacity of $419 \mathrm{MW}$ of electricity. Preliminary generation potential, for which applications have not yet been received, could add a further $1125 \mathrm{MW}$ of electricity. ${ }^{20}$

The proposed $\$ 1.35$ billion Brooks Power project, $180 \mathrm{~km}$ southeast of Calgary, includes a coal-fired electricity generation plant and surface coal mine. ${ }^{21}$ The project calls for two 500-megawatt generating units. The project will use low-sulphur coal and state-of-the-art supercritical technology to ensure emissions produced meet Alberta's environmental standards.

Alberta's transmission policy supports a robust transmission system to ensure system reliability and to enable future generation development. The Independent System Operator is responsible for overall transmission system planning and development, and has proposed major upgrades to the Edmonton-Calgary and southwest Alberta transmission lines to facilitate new generation development and system reliability.

\subsubsection{Industry Forecasts}

Alberta has the world's largest repository of hydrocarbon resources, with significant coal reserves, $75 \%$ of global oil sands, and enough natural gas to heat Alberta homes and provide clean hydrogen ${ }^{22}$ for a century. These abundant resources virtually guarantee the province a key role in future national and international energy production and export.

The Alberta Energy Research Institute (AERI) asserts that the sector's prosperity lies in efficient and environmentally sensitive production, including:

- $\quad$ Carbon dioxide (CO2) management/storage program;

- Clean coal technology;

- Increased oil recovery using $\mathrm{CO} 2$; and

- Development of hydrogen, bioenergy and new energy technologies.

The Alberta Energy Research Institute (AERI) predicts Alberta's petrochemical industry will undergo a major transition in the next 25 years, as traditional feedstock (e.g., natural gas liquids) declines in the face of increasing petrochemical demand.
AERI also predicts Alberta's petrochemical industry will undergo a major transition in the next 25 years, as traditional feedstock (e.g., natural gas liquids) declines in the face of increasing petrochemical demand. Programs using different feedstock, such as coal,will put Alberta at an advantage given its coal reserves. Furthermore, increased regional, national, and international coal demand is anticipated to meet growing electrical needs. Development of Alberta's natural gas in coal is likely to increase in this time and may supplement conventional natural gas reserves. Wind power promises both energy and lower provincial greenhouse gas emissions that may be necessary if/when environmental agreements, such as the Kyoto Protocol, are implemented. ${ }^{23}$

\section{Demand forecasts}

The EUB anticipates that global oil prices will be sufficient to stimulate exploration outside of OPEC countries, fostering improvements in exploration and recovery technology. Alberta's hydrocarbon growth potential is highly dependent upon natural gas. While recent volatility in natural gas prices is expected to continue in the shortterm, the direct and indirect impacts of oil sands expansions, along with the expansion of other economic sectors, will boost Alberta's GDP to grow at an annual average of $4 \%$

\footnotetext{
${ }^{20}$ AESO. http://www.aeso.ca/files/SouthW AB trans dev plan.pdf. (19 Jan 2005).

${ }^{21}$ Natural Resources Canada. http://www. nrcan.gc.ca/mms/cmy/2003revu/coal e.htm (19 Jan 2005)

${ }^{22}$ Refers to deriving hydrogen from clean, renewable energy sources as opposed to extraction from fossil fuels.

${ }^{23}$ Alberta Energy Research Institute Website http://www.aeri.ab.cal (17 Nov. 2004)
} 
The 45, 140 farm workers employed in Southern Alberta represent $66.2 \%$ of the 68,200

employed in Alberta's agricultural labour force

thru 2012. The province's remaining conventional oil reserves have been reduced by half since 1990 . The EUB believes that global crude oil prices will play a major role in drilling activity thru 2012, and expects that crude oil prices will be stable, resulting in healthy activity in drilling for crude oil through until $2012 .^{24}$

\subsection{Agriculture Sector}

\subsubsection{Industry Overview}

Agriculture, and the many industries that support it, are the dominant business in much of southern Alberta. Cattle, grain, corn, potatoes and sugar beet production continue to be important to the region, but producers have also branched into many new crop types and varieties including improved pulses, medicinal and nutraceutical herbs. Dairy, pigs, and food and beverage processing are all important contributors to the agricultural economy. Advanced research facilities in the Lethbridge area have supported the development of a science-based approach to farm management and irrigation infrastructure. This in part has led to a strong established livestock industry, including confined feeding operations and packing plant facilities. In addition, heavy investment in transportation infrastructure has provided access to U.S. markets.

The SAL region's agricultural base reflects the geographic diversity of the area: ranching is important in the foothills and drier parts of the region, grains/oilseed production, mixed farming and confined feeding operations occur north to south in the central portion, forage and specialty crops are grown on irrigated land, while the drier eastern and extreme southern portions of the region are dominated by tame pasture and native rangelands. Currently, there are more than 40 different crops being grown in southern Alberta, and crop diversity supports value-added processing. ${ }^{25}$ A summary of the type of farms and farm employment within the SAL region is shown in Figure 2-2.

Figure 2-2

Farms and Farm Employment by Census District (2001 Census)

\begin{tabular}{|l|c|c|c|c|c|c|c|c||}
\hline \multirow{2}{*}{ Census District } & \multirow{2}{*}{$\begin{array}{c}\text { Farm } \\
\text { Employ- }\end{array}$} & \multirow{2}{*}{$\begin{array}{c}\text { Labour } \\
\text { ment }\end{array}$} & Force & & \multicolumn{3}{|c|}{ Number of Farms Growing Selected Products } & \multirow{2}{*}{ Total \# } \\
\cline { 5 - 9 } & & & & & & $\begin{array}{c}\text { Cattle/ } \\
\text { Calves }\end{array}$ & Hogs & \\
\hline Farms
\end{tabular}

Source: www.albertafirst.com/profiles/

NOTE: Census Districts do not exactly delineate the SAL region boundaries. The SAL region includes portions of Census Districts 4 (99.1\%), $7(19.8 \%), 8(83.5 \%), 9(15.2 \%)$ and $15(86.1 \%)$ that are shown above. Not included in the table are Census Districts 10 and 11 , for which the SAL region encompasses $1.6 \%$ and $0.04 \%$ respectively.

\footnotetext{
${ }^{24}$ Alberta Energy and Utilities Board Website http://www.eub.gov.ab.ca/bbs/energystats/default.htm (17 Nov. 2004)

${ }^{25} \mathrm{http}: / / \mathrm{www} 1$. agric.gov.ab.ca/\$department/deptdocs.nsf/all/irr7197
} 
With an average annual rainfall in southern Alberta of 300 to $450 \mathrm{~mm}$, half of which falls during the growing season, water is an important commodity, and its distribution and allocation is critical to successful farming within much of the region.

\section{Almost half of the province's public rangeland is under grazing leases, licenses, or permits to farmers and ranchers throughout the province, under supervision of the Rangeland Management Branch of Alberta Sustainable Resource.}

The southern Alberta region accounts for a significant proportion of Alberta's total agricultural output, accounting for $73 \%$ of provincial agricultural sales. Total sales in 2001 , including crops, livestock, confined feedlot operations, meat packing and food processing totaled $\$ 10.4$ billion. Based on 2001 census data, the region had more than 25,500 farms, of which more than one-half $(16,071)$ were cattle/livestock farms. There were 45,140 farm workers in the region, representing $66.2 \%$ of Alberta's agricultural labour force. ${ }^{26}$

\section{Dryland Farming}

Dryland farming occurs on land that produces a crop with the natural moisture supplied by the weather. Most of the agricultural land in southern Alberta is devoted to dryland farming $(83 \%)$. The climate in southern Alberta is continental, with short, warm summers and long, cold winters. The area extends east of the Rocky Mountains, and is characterized by strong, warm, and dry Chinook winds in the winter. However, Chinook conditions hasten the loss of any snow cover and significantly influence overwinter soil temperature and moisture conditions. For dryland farmers, some of the considerations surrounding moisture conditions include crop selection, fertilizer application rates, seeding dates and seeding depths. The most common crops grown on dryland farms are wheat, barley, canola, alfalfa and tame hay.

\section{Irrigation}

Alberta is the irrigation capital of Canada, with approximately $65 \%$ of the nation's irrigation infrastructure. Irrigated area accounts for about $17 \%$ of southern Alberta's agricultural land, but the economic benefit of this land is the employment of approximately 35,000 people and the generation of $\$ 940$ million a year for the provincial economy. Irrigation helps to support the largest beef cattle industry in Canada, along with the pork, poultry, specialty meat, and dairy industries. Irrigation systems have made potato production viable and forage relatively inexpensive. Irrigation allows $6 \%$ of Alberta's cultivated land base to produce $19 \%$ of the value of the province's gross primary agricultural production. ${ }^{27}$

Water for irrigation in southern Alberta comes from five sources: the Red Deer, Bow, Oldman, South Saskatchewan and Milk river basins. There are more than 8,000 kilometres of conveyance works and more than 50 water storage reservoirs devoted to managing water resources. There are about 625,000 hectares of productive irrigated land, mainly within 13 irrigation districts. Irrigation infrastructure also provides water for about 50 rural communities, thousands of farms and small rural industries.

\section{Ranching}

Alberta rangelands, which includes grassland, grazeable forestland, shrubland, and pastureland are extensive, covering an estimated 7.4 million hectares. The majority of rangeland in the province is found in southern Alberta. Rangelands are an important agricultural resource for livestock grazing, providing approximately $20 \%$ of the forage required by the Alberta beef cattle herd. The rangeland is a key part of cow-calf operations, where cows are bred annually and calves are sold to a finisher shortly after they are weaned.

\footnotetext{
${ }^{26}$ NOTE: Census Districts do not exactly delineate the SAL region boundaries. The SAL region includes portions of Census Districts 4 (99.1\%), 7 (19.8\%), $8(83.5 \%), 9(15.2 \%)$ and $15(86.1 \%)$ that are shown above. Not included in the table are Census Districts 10 and 11 , for which the SAL region encompasses $1.6 \%$ and $0.04 \%$ respectively.

${ }^{27}$ Alberta Agriculture, Food and Rural Development Website

http://www1 agric.gov.ab.ca/\$department/deptdocs.nsf/all/irr7197 (02 Dec. 2004)
} 
About $62 \%$ of southern Alberta's rangelands are under public ownership and administration. Almost half of the province's public rangeland is under grazing leases, licenses, or permits to farmers and ranchers throughout the province, under supervision of the Rangeland Management Branch of Alberta Sustainable Resource Development.

\section{CFO Livestock}

Confined feeding operations (CFO) are defined as fenced or enclosed areas for growing, sustaining, finishing or breeding livestock by means other than grazing. The province has about 4,500 cattle feedlots, and just over half of the province's cattle are finished in 30 of the largest operations, which are located mainly between Calgary and Lethbridge in an area commonly referred to as "Feedlot Alley."28 Two major meatpacking facilities, IBP-Tyson's Lakeside plant at Brooks and Cargill's Excel plant at High River, are located in the SAL region. These two facilities slaughter over $60 \%$ of all the beef processed in Canada. In addition, there are about 1.5 million hogs and extensive poultry in confined feedlot operations in southern Alberta. Confined feedlots in southern Alberta generate about $\$ 4$ billion in annual sales.

\subsubsection{Industry Trends}

\section{Economic Performance}

Alberta exported $\$ 5.1$ billion of primary and processed agrifood products in 2002 to over 100 countries around the world.
In 2004, total farm cash receipts in Alberta's agricultural sector were up 8.5\% compared to 2003, primarily due to higher crop receipts. It should be noted, however, that 2003 cash receipts were the lowest in three years. Farm cash receipts represented $21 \%$ of the value of Canada's total agricultural production. Overall, crop receipts in 2004 should be above the 10-year average, however, excessive summer rainfall and poor weather conditions in the early fall reduced crop quality. ${ }^{29}$ This was in contrast to livestock receipts, which were down $9 \%$ over the same period, with cattle receipts declining by $14.7 \%$ due to the ongoing economic effects from the BSE crisis. ${ }^{30}$ Real GDP output in the agricultural sector is expected to decline by $2.2 \%$ in 2004 and $1.7 \%$ in $2005^{31}$

Alberta exported $\$ 4.2$ billion in primary and processed agricultural and food products in $2003,19.5 \%$ lower than the $\$ 5.1$ billion in 2002, mainly due to BSE imposed trade restrictions, effects of the severe 2002 drought, and the appreciation of the Canadian dollar. About $59 \%$ or $\$ 3$ billion of all agri-food exports went to the United States in 2002. Exports of value-added products fell $18.8 \%$ to $\$ 2.4$ billion and exports of animals and crops fell to $\$ 1.8$ billion, or $20.5 \%$. Exports of grains declined, with both wheat and barley exports falling $13 \%$ each, while canola seed exports rose $39 \%$. The closure of international borders for cattle and beef products severely affected the respective industries, as $48.5 \%$ of total agri-food exports are destined for the U.S. market. ${ }^{32}$

In spite of the decline in exports in 2003, more than a billion dollars of food, non-food and beverage capital investment has been made in Alberta since 1995. Recent examples include two $\$ 100$ million french fry plants, a new $\$ 40$ million grain fractionation and processing facility, a new $\$ 25$ million baking facility, and expansions in excess of $\$ 40$ million in the sugar industry. ${ }^{33}$

${ }^{28}$ J.D. Price. "Murky Waters: Are factory farms fouling our water?".

http://www.albertaviews.ab.ca/mayjun03/mayjun03cfo.pdf (18 Jan 2005)

${ }^{29}$ The Conference Board of Canada. Provincial Outlook: Autumn 2004.

${ }^{30}$ Alberta Economic Development. Economic Update: October 2004.

${ }^{31}$ The Conference Board of Canada. Provincial Outlook: Autumn 2004.

${ }^{32}$ Alberta Agriculture Food \& Rural Development Website http://www1.agric.gov.ab.ca/\$department/deptdocs.nsf/ba3468a2a8681f69872569d60073fdel/3895e3d3d03e02fb8725 6bdb006bdd98/SFILE/Factsheet.pdf (01 Dec. 2004)

${ }^{33} \mathrm{http} / / / \mathrm{www} 1 . a g r i c . g o v . a b . c a / \$ d e p a r t m e n t / d e p t d o c s . n s f / a l l / a g p 6158$ 


\section{Alberta's}

agricultural sector

faces significant

challenges as a

result of the U.S.

import ban on live

cattle.

\section{Trade Factors}

With the exception of live cattle, Alberta exports of animals and animal products have tripled or quadrupled since NAFTA's inception. ${ }^{34}$ The occurrence of BSE in North America brought unexpected challenges to the agricultural industry of southern Alberta. The U.S. import ban and border closure to live cattle and some beef products due to BSE significantly reduced the value exports of live cattle to North American Free Trade Agreement (NAFTA) countries from \$635 million in 2002 to $\$ 196$ million in $2003 .^{35}$ Likewise, fresh or chilled beef exports fell from $\$ 1.37$ billion in 2002 to $\$ 936$ million in 2003. Exports of live swine also fell, from \$76 million in 2002 to \$54 million in 2003. Much of the livestock that could not be exported to the U.S. is now being processed in Canada and exported as processed product. ${ }^{36}$

Total world trade continues to grow rapidly, however nearly all the growth has been in consumer oriented trade, as opposed to bulk commodities. ${ }^{37}$ The potential for growth appears to be in consumer oriented, value-added products. The food-processing sector is likely to grow, fuelled by the development of new and unique products such as ethnic foods, nutriceuticals and functional foods. Other areas of growth are the more traditional processing of crops, crop products, and beverages. There are also significant opportunities for added value production in the industrial uses area, including special lubricants and hydraulic oils, fibre-board and other fibres. Trade factors that could have negative impact include European restrictions on genetically modified organisms (GMOs).

\section{Government Legislation and Policy}

Due to the substantial reductions in both crop and livestock market receipts, program payments escalated in 2003 as both provincial and federal governments took steps to address the effects of the 2002 drought and the BSE incident. Total direct program payments to Alberta farmers escalated in 2003 to a record $\$ 1.36$ billion, up $31.1 \%$ from the previous record of $\$ 1.04$ billion paid out in $2002 .^{38}$ An additional $\$ 230$ million in provincial program assistance was announced in September 2004. Strategies included measures to address slaughter capacity and cattle over-supply, BSE surveillance, crop insurance, and disaster income assistance including enhancements to the Canadian Agricultural Income Stabilization Program ${ }^{39}$.

The agricultural policy framework is a comprehensive federal-provincial-territorial policy agreement that covers significant and diverse aspects of the agriculture industry. The aim is to develop a framework for government policy that will provide the tools for industry to adapt to rapid advances in technology, compete in an increasingly complex global market, and respond to changing consumer demands.

The Environmental Farm Plan program provides a voluntary, confidential selfassessment process for agricultural producers to evaluate the environmental risks and strengths of their operations and develop a plan to address those risks and strengths. A non-profit company, comprised of industry, government, and other stakeholders, develops and administers the program in Alberta. Through a five-year initiative, the

\footnotetext{
${ }^{34}$ Western Centre for Economic Research. Information Bulletin \#80.

${ }^{35}$ Alberta Government Website http://www.gov.ab.ca/home/index.cfm?Page=929 (01 Dec. 2004)

${ }^{36} \mathrm{http}: / / \mathrm{www} . n$ ewswire.ca/en/releases/archive/October2004/06/c7347.html

${ }^{37} \mathrm{http}: / / \mathrm{www} 1$.agric.gov.ab.ca/ $/$ department/deptdocs.nsf/all/agp6158

${ }^{38}$ Alberta Agriculture Food \& Rural Development Website. http://www1.agric.gov.ab.ca/\$department/deptdocs.nsf/all/sdd8159?opendocument (18 Jan 2005)

${ }^{39}$ Alberta Agriculture Food \& Rural Development Website http://wwwl agric.gov.ab.ca/\$department/deptdocs.nsf/all/com9040?opendocument (01 Dec. 2004)
} 
Government of Canada is investing $\$ 48.8$ million, and the Alberta Government providing $\$ 32.6$ million of in-kind support services, to assist producers in developing environmental farm plans. ${ }^{40}$

In 2002 the Government of Alberta superseded local government's right to implement by-laws for and impose conditions on Confined Feeding Operations (CFOs) by amending Alberta's Agricultural Operation Practices Act. ${ }^{41}$ The purpose of the amendments was to provide provincial wide standards that promote an environmentally sustainable livestock industry, and to give the province the authority and responsibility for the siting, monitoring and enforcement of all new and expanding CFOs in Alberta. Amendments also included provisions for a process to deal with nuisance complaints from agricultural practices. AOPA defines a confined feeding operation as "an activity on land that is fenced or enclosed or within buildings where livestock are confined for the purpose of growing, sustaining, finishing or breeding by means other than grazing, but does not include seasonal feeding and bedding sites".

\subsubsection{Major Projects}

Figure 2-3

Major Agricultural Projects within the SAL Region (Proposed, Announced or Currently Under Construction)

\begin{tabular}{|c|c|c|c|c|}
\hline Company Name & Description & Location & Cost (millions) & Status/Completion \\
\hline $\begin{array}{l}\text { (Various Irrigation } \\
\text { Districts) }\end{array}$ & $\begin{array}{c}\text { Irrigation Systems/ } \\
\text { Rehabilitation }\end{array}$ & Southern Alberta & $\$ 600$ & $\begin{array}{c}\text { Under construction } \\
1997-2006\end{array}$ \\
\hline Special Areas Board & $\begin{array}{l}\text { Special Areas Water } \\
\text { Supply Project }\end{array}$ & $\begin{array}{l}\text { Near Stettler to } \\
\text { Special Area } 2\end{array}$ & $\$ 190$ & Proposed \\
\hline $\begin{array}{l}\text { Northwest Cattlemen's } \\
\text { Alliance }\end{array}$ & Meat Packing Plant & Lethbridge area & $\$ 100$ & Proposed \\
\hline $\begin{array}{l}\text { New Generation } \\
\text { Processors Co-op }\end{array}$ & $\begin{array}{l}\text { 'Southwest Packers' } \\
\text { Meat Packing Plant }\end{array}$ & Pincher Creek & $\$ 40$ & $\begin{array}{c}\text { Under construction } \\
(\text { phase } 1)^{42}\end{array}$ \\
\hline Cargill Foods ${ }^{2}$ & $\begin{array}{l}\text { Cattle Harvesting } \\
\text { Expansion }\end{array}$ & High River & $\$ 32.5$ & $\begin{array}{c}\text { Nearing completion } \\
\text { (phase 2) - Phase } 3 \\
\text { planned for June } \\
2005\end{array}$ \\
\hline Rancher's Beef Ltd. & Beef Processing Plant & $\begin{array}{c}\text { MD of Rocky } \\
\text { View (near Balzac) }\end{array}$ & $\$ 30$ & $\begin{array}{l}\text { Under Construction } \\
2005\end{array}$ \\
\hline Sunrise Poultry & $\begin{array}{l}\text { Poultry Processing } \\
\text { Plant and Hatchery }\end{array}$ & Lethbridge & $\$ 20$ & $\begin{array}{c}\text { Under construction } \\
2004-2005 \\
\end{array}$ \\
\hline Lakeside Packers & Facility Expansion & Brooks & $\$ 17$ & Announced 2005 \\
\hline Olymel & Plant Expansion & Red Deer & $\$ 14$ & Announced 2005 \\
\hline Frito Lay Canada & Mechanical Upgrades & Taber & $\$ 7$ & $\begin{array}{l}\text { Under construction } \\
2005 \\
\end{array}$ \\
\hline $\begin{array}{l}\text { Clean Energy } \\
\text { Combustion Systems/ } \\
\text { Pure Produce } \\
\text { Greenhouses Killam Inc. }\end{array}$ & $\begin{array}{l}\text { Hydroponic } \\
\text { Greenhouses }\end{array}$ & Killam & $\$ 5$ & Proposed \\
\hline Pioneer H-Bred & $\begin{array}{l}\text { Office, Warehouse, and } \\
\text { Seed Cleaning and } \\
\text { Treating Plant }\end{array}$ & Lethbridge County & $\$ 5$ & $\begin{array}{l}\text { Announced 2005- } \\
2006\end{array}$ \\
\hline
\end{tabular}

${ }^{40}$ Agriculture, Food and Rural Development website.

http://wwwl agric.gov.ab.ca/Sdepartment/deptdocs.nsf/all/com8528?opendocument (18 Jan 2005)

${ }^{41}$ Alberta Agriculture Food \& Rural Development Website

http://wwwl agric.gov.ab.ca/\$department/newslett.nsf/all/stan2943 (01 Dec. 2004)

${ }^{42}$ Phased development to include a slaughter plant, followed by value-added projects and bio-digester. 
Figure 2-3 (cont'd)

\begin{tabular}{|lcccc|}
\hline Company Name & Description & Location & Cost (millions) & Status/Completion \\
\hline \hline TK Ranch Natural Meats & Slaughter Plant & $\begin{array}{c}\text { Special Area 2 } \\
\text { (Hanna) }\end{array}$ & $\$ 4$ & Proposed 2005 \\
\hline Sunterra Meats Ltd. & $\begin{array}{c}\text { Processing Plant } \\
\text { Expansion }\end{array}$ & Innisfail & $\$ 2.5$ & $\begin{array}{c}\text { Completed 2004- } \\
2005\end{array}$ \\
\hline
\end{tabular}

Sources: www.alberta-canada.com/statpub/conspro.cfin, except for:

1. http://www.finance.gov.ab.ca/publications/budget/budget2004/eco.pdf,

2. http://www.cargill.ca/press/articles/2004/aug_30.htm.

The forest sector has invested over $\$ 5$ billion in new capital expenditures and upgrades, giving Alberta some of the most efficient and environmentally friendly plants in the world.

\subsection{Forestry Sector}

\subsubsection{Industry Overview}

Approximately $16 \%$ of the SAL region is forested. About $41 \%$ of this forest land base is public land, while most of the balance is either freehold or located within federal or provincial parks. Within the project boundary are two forest management agreements, two community timber programs, and four coniferous timber quotas. This region also has three primary forest product-manufacturing facilities (sawmills), and many smaller facilities (e.g., sawmills, round-wood processing facilities, log home manufacturers, and remanufacturing plants). Communities within the SAL region that have a high dependence on forestry include Sundre, Blairmore, Cowley, and Cochrane. ${ }^{43}$

In 2003, there were 9,100 people employed in the forestry industry in southern Alberta $^{44} ; 4,200$ people were directly employed and 4,900 jobs resulted from indirect or induced employment. ${ }^{45}$ In 2000 , there were 15 major employers, with a total sawmill capacity of 108,250 thousand board feet of lumber, pulp \& paper capacity of 59,000 airdried metric tonnes, and value-added capacity of $110,263,230$ thousand board feet.

Direct and indirect revenue from these operations totaled $\$ 2.3$ billion, with expenditures totaling $\$ 2.4$ billion. A large state-of-the-art sawmill in Sundre has a capacity of 190,000 thousand board feet of lumber, along with wood treating and post-manufacturing facilities. ${ }^{46}$

The forestry sector has invested over $\$ 5$ billion in new capital expenditures and upgrades, giving Alberta some of the most efficient and environmentally friendly plants in the world. On average, each mill spends upwards of $\$ 250,000$ a year monitoring, upgrading, and developing new technology to protect and continually improve the quality of Alberta's water resource. The forestry industry also monitors air quality, at its own expense, to meet or exceed provincial standards. ${ }^{47}$

\subsubsection{Industry Trends}

Factors affecting the industry include ensured access to global markets, maintenance of certification regimes, adherence to sustainable forest management practices, maintaining

${ }^{43}$ Alberta Forest Products Association Website. http://www.albertaforestproducts.ca/document library/communities.pdf. (30 Nov. 2004).

44 Note: Employers in the region includes Sunpine Forest Products in Rocky Mountain House

${ }^{45} \mathrm{C}$. Scott, personal communication, March 30, 2005.

${ }^{46}$ Alberta Forest Products Industries. 2001. "Overview and Economic Impact." http://www3.gov.ab.ca/srd/forests/managing/business/pubs/AlbertaForestProductsIndustries.pdf (18 Jan 2005)

${ }^{47}$ Alberta Forest Products Association Website. http://www.albertaforestproducts.ca/industry/facts figures.aspx. (30 Nov. 2004). 
a productive and stable land base, and integrated planning and operating of activities.

Sustainable Forest Management system standards are being used as a tool by

organizations to continually improve their management systems and to ensure field

performance is consistent with the goal of sustainable forest management. Furthermore, certification systems are being used by industry to secure and maintain access to global markets as part of their economic sustainability.

\section{Technology}

The businesses involved in Alberta's forestry sector are working to increase the value of forest resource products by enabling innovation, increasing global competition in valueadded products, and leading in research and learning opportunities. For example, recent advances in hybrid poplar research may soon provide a sustainable crop that is economically viable for private lands. In experimental plots, some of the best growth has been obtained from cultivars of Populus deltoides, a species native to southern Alberta. ${ }^{48}$ Biotechnology is also increasingly viewed as a potential means to meet market growth needs for forestry products, such as pulp fibre.

New practices and technology allow Alberta's forest product companies to use virtually all of the wood harvested, using materials that were formerly considered waste and burned. Ongoing research offers opportunities for the continued development of valueadded wood products. More environmentally friendly processing plants operate with increased efficiency and generate fewer emissions to the atmosphere. In addition, new technology has virtually eliminated the discharge of toxins and furans in the production of pulp and paper. ${ }^{49}$

\section{Economic Performance}

In 1984, Alberta's forest product shipments were less than $\$ 1.0$ billion. Total forest industry shipments reached approximately $\$ 4.7$ billion in 2003 , with exports of $\$ 2.8$ billion. During this time, the forest industry in Alberta has moved from being primarily a manufacturer of commodity lumber to a diversified sector, which includes the production of lumber, pulp, oriented strandboard, medium density fibreboard, remanufactured products, engineered building products, prefabricated buildings, cabinets, and furniture. Each year, up to 24.2 million cubic metres can be harvested in the province, of which 13.8 million cubic metres is allocated for conifers and 10.4 million cubic metres is allocated for deciduous trees.

\subsubsection{Major Projects}

There are no major forestry projects listed within the SAL region.

\subsection{Tourism Sector}

\subsubsection{Industry Overview}

SAL's tourism industry has a number of strengths, which include strong product offerings such as the natural beauty of the national parks, Kananaskis Country, modern cities, natural history and historic sites, and museums. As the provincial population grows, so will the increasing importance of the SAL area to the tourism industry as will

\footnotetext{
${ }^{48}$ Poplar Council of Canada. http://www.poplar.ca/n200109e.htm. (18 Jan 2005).

49 Alberta Forest Products Association Website. http://www.albertaforestproducts.ca/industry/facts figures. aspx . (30 Nov. 2004).
} 
increasing global travel demands. The growth and vitality of Calgary will continue to draw visitors to the region as will the international perception that Canada is a peaceful nation free of terrorist targets.

\section{Tourism Destination Regions}

The SAL region spans four of Alberta's Tourism Destination Regions. All of the Calgary area and Southern Alberta Tourism Destination Regions are within SAL, and a portion of the Central and Rockies Tourism Destination Regions are also covered by SAL. ${ }^{50}$

In 2001, an estimated $\$ 2.2$ billion tourism dollars were spent in the SAL region.

About half of Alberta's tourism occurs within the SAL area. In 2001, an estimated $\$ 2.2$ billion tourism dollars were spent in this region, approximately $41 \%$ of provincial tourism receipts for that year. The top five accommodation locations within the SAL region were Banff, Calgary, Kananaskis Country, Red Deer and Canmore. ${ }^{51}$

\section{Facilities and Attractions}

The SAL region has many tourism facilities and attractions. Provincial recreation areas, natural areas, and provincial parks make up most of the parks in the SAL area, which includes 206 designated parks and wilderness areas. In 2001, there were over 25,000 fixed roof accommodations and over 19,000 campsites. Kananaskis Country is home to 36 provincial recreation areas, four provincial parks and four wilderness areas. The SAL region contains 140 golf courses, eight ski hills, numerous sports complexes, local and provincial museums, cultural and sporting events, and trails and destination areas for motorized \& non-motorized recreation. ${ }^{52}$ A key tourism attraction in the region is the Calgary Exhibition and Stampede, which occurs each summer, typically in earlyJuly. This event is estimated to attract more than one million visitors to the region from Alberta, Canada, the United States, and abroad.

\subsubsection{Industry Trends}

A number of trends are expected to shape the future of tourism product demand in the SAL region. Future travelers will look increasingly toward quality and value, and will seek new destinations and experiences that provide education, rest, and relaxation. Culture, history, and diversity are key educational themes, and older travelers will desire comfortable accommodations on the "doorstep" of attractions. The appeal of the mountains will continue to draw travelers of all types, including those seeking "soft" or "hard" outdoor adventure. ${ }^{53}$

In Alberta, between 1996 and 2001, tourism receipts grew from $\$ 3.5$ billion to $\$ 5.4$ billion; a $54 \%$ increase. ${ }^{54}$ This growth is due in part to Alberta's tourism industry expanding from a "one season operation" to a multifaceted four-season industry. While Alberta's traditional tourism sectors, such as hunting, fishing and skiing, continue to attract visitors, the sector has also benefited from the growth of new attractions, including ecotourism and adventure vacations. ${ }^{55}$

${ }^{50} \mathrm{http} / / / \mathrm{www} . a$ lberta-canada.com/tdb/abtourop.cfm (09 Dec. 2004)

${ }^{51}$ Alberta Economic Development. Tourism Sector Overview. Southern Alberta Landscapes: Meeting the Challenges Ahead. PowerPoint Presentation.

52 Alberta Economic Development. Tourism Sector Overview. Southern Alberta Landscapes: Meeting the Challenges Ahead. PowerPoint Presentation.

${ }^{53}$ Alberta Economic Development. Tourism Sector Overview. Southern Alberta Landscapes: Meeting the Challenges Ahead. PowerPoint Presentation.

${ }^{54} \mathrm{http}: / / \mathrm{www} . a l b e r t a-c a n a d a . c o m / s t a t p u b / p d f /$ frequentTourismQuestions.pdf (09 Dec. 2004)

55 Alberta Economic Development. Tourism Sector Overview. Southern Alberta Landscapes: Meeting the Challenges Ahead. PowerPoint Presentation. 
After the terrorist attacks in September 2001, the number of person trips declined, falling $7.9 \%$ in 2002, and a further $17.8 \%$ in 2003. In 2003, the majority of Alberta's tourists were Albertans (74.0\%); 17.2\% were other Canadians, 5.4\% were American, and $3.4 \%$ came from other nations. While non-Alberta tourists account for $26.0 \%$ of the total tourists, they contributed $51.8 \%$ of Alberta's tourism revenues. ${ }^{56}$

International tourism is predicted to remain a growth industry. Continued development of the industry in Alberta will be supported by the growth of international travel, increased national and international marketing, provincial population growth, and changing demographics. Opportunities for SAL's future tourism industry include the following:

- Develop, market, and link its western hospitality, mountains, foothills, forests, badlands, and outdoor adventure products (during all four seasons) with the amenities of modern cities, and a rich, diverse culture and history;

- Create sustainable products (e.g., ecotourism, nature, culture-based);

- Trends in technology (e.g., internet) provide opportunities for small tourism operators to market themselves; and

- Develop a strategic integrated approach to resolving land allocation and policy issues to promote industry growth.

\subsection{Manufacturing Sector}

The manufacturing sector was the second largest contributor after primary industries in the Calgary area, contributing $\$ 5.4$ billion each year.

\subsubsection{Industry Overview}

Alberta is Canada's leading petrochemical producer. Agri-food manufacturing is another large industry in southern Alberta, with more than 130 businesses producing food and/or feed for local consumption and export. Altogether, Alberta is ranked third in Canada in manufacturing output with over 10,000 value-added manufacturers. In 2002, approximately 147,100 Albertans were employed in manufacturing industries, and half of those were employed within the SAL region. Not surprisingly, manufacturing is clustered around the major urban centres. Alberta's manufacturing sector is closely tied to the resource sector, with about two-thirds of manufacturing output consisting of value-added resource products. ${ }^{57}$ Industries that are well established in the province's manufacturing sector include petrochemicals, agri-foods, commercial and industrial equipment and machinery, metal products, value-added wood and building products. Emerging industries include aerospace, biotechnology and telecommunications equipment manufacturers. Meat and meat products contribute over half of the total value of shipments for Alberta's food and beverage industry. The red meat sector was ranked as Alberta's third largest manufacturing industry with sales of $\$ 3.7$ billion in 2001 .

The SAL region contributes to a significant part of Alberta's manufacturing output: $91 \%$ of its meatpacking, $52 \%$ of its food processing and $47 \%$ of other manufacturing. In 2001 , approximately $70 \%$ of manufacturing in the SAL region occurred in the Calgary area, with other significant manufacturing activity occurring in Lethbridge and Red Deer. Lethbridge had the highest per capita density of manufacturing employment,

${ }_{57}^{56} \mathrm{http}: / /$ www.alberta-canada.com/statpub/pdf/frequentTourismQuestions.pdf (09 Dec. 2004)

57 Alberta Economic Development. Highlights of the Alberta Economy: Winter2004. http://www.albertacanada.com/statpub/pdf/news_HighlightsWinter2004.pdf (01 Dec 2004). 
17

comprising $10.6 \%$ of the labour force in 2001 , followed by Calgary ( $8.7 \%$ ) and Medicine Hat (8.1\%). 
The value-added wood and building products industry is composed of many small- to medium-sized firms, with $90 \%$ of companies generating revenues of $\$ 10$ million or less, and $46 \%$ of companies with revenues of $\$ 1$ million or less.

Figure 2-4

Manufacturing Labour Force by Census District (2001)

\begin{tabular}{|l|c|c|}
\hline Census District (CD) & $\begin{array}{c}\text { Manufacturing } \\
\text { Employment }\end{array}$ & $\begin{array}{c}\text { \% of CD Labour } \\
\text { Force }\end{array}$ \\
\hline \hline Lethbridge & 7,540 & $10.6 \%$ \\
\hline Calgary & 52,665 & $8.7 \%$ \\
\hline Medicine Hat & 2,930 & $8.1 \%$ \\
\hline Red Deer & 6,185 & $7.3 \%$ \\
\hline Fort Macleod & 1,045 & $6.0 \%$ \\
\hline Drumheller & 1,415 & $5.8 \%$ \\
\hline Rocky Mountain House & 515 & $4.8 \%$ \\
\hline Banff & 645 & $3.0 \%$ \\
\hline Stettler & 550 & $2.5 \%$ \\
\hline Hanna & 50 & $0.8 \%$ \\
\hline \hline TOTAL & $\mathbf{7 3 , 5 4 0}$ & - \\
\hline
\end{tabular}

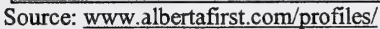

NOTE: Census Districts do not exactly delineate the SAL region boundaries. Not included in the table are Census Districts 10 and 11 , for which the SAL region encompasses $1.6 \%$ and $0.04 \%$ respectively.

\section{The City of Calgary}

The manufacturing sector was the second largest contributor after primary industries in Calgary, contributing \$5.4 billion each year. The average annual growth rate in GDP in the sector between 1997 and 2001 was $4.3 \%$, with annual employment growth averaging $5.6 \% .{ }^{58}$ In 2001, the largest manufacturing industries in Calgary were food products ( $21.6 \%$ of the total value of shipments), petroleum and coal products $(17.5 \%)$, and chemicals and chemical products $(16.4 \%)$.

\section{Cities of Lethbridge and Medicine Hat}

Lethbridge is the second largest hub for manufacturing industries within the SAL region. Geographically located in the heart of the province's agricultural region, the city is home to a significant number of food and beverage industries. There are numerous manufacturers involved in meat processing, snack foods, vegetable oil processing, flour milling, and distilling. Likewise, there are many small- to medium-sized firms manufacturing farm machinery and equipment.

Other major manufacturing industries in the Lethbridge include primary metals and metal fabricators, producing goods such as aluminium extrusions, sheet metal products, ferrous castings, waste disposal equipment, trailers, drill rig frames and structural steel. Two large manufactured housing plants operate in the region, employing 400 people. There are many small firms involved in the value-added manufacture of commercial and residential furniture and wood products, trusses, wooden and aluminium windows and doors. Three advanced technology firms in Lethbridge are involved in the manufacture of products including cable and electronics, printed circuit boards, and aircraft engines. ${ }^{59}$

Medicine Hat is a commercial, manufacturing, and transportation center situated in an agricultural and natural gas producing region. Manufacturing is one of the strongest sectors of the Medicine Hat economy, producing a variety of industrial and consumer goods for domestic and export markets. Major manufacturers include processed food, clay and glass products, chemicals including fertilizer compounds, thermal carbon black, gasoline catalyst compounds, tires, commercial and industrial equipment and machinery. ${ }^{60}$

\footnotetext{
${ }^{58}$ The Calgary Advantage. 2002. Business \& Industry. Edition 1.

${ }^{59}$ Economic Development Department. Lethbridge Community Profile 2002-2003. The City of Lethbridge.

${ }^{60}$ Alberta First Website. http://www.albertafirst.com/profiles/statspack/20375.html (26 Nov. 2004)
} 
The Red Deer area in south-central Alberta is the third largest manufacturing centre in the $S A L$ region, recording over \$3.35 billion in sales for 2003.

\section{The City of Red Deer and Central Alberta}

The Red Deer area in south-central Alberta is the third largest manufacturing centre in the SAL region, recording over $\$ 3.35$ billion in sales for 2003 . The two largest manufacturing sectors for employment are food and beverage products and chemical and allied products. There are close to 200 manufacturers in the Red Deer region, including more than 50 agri-food and agricultural products companies.

As a major centre for cattle, swine and chicken production, there are 17 meat processing businesses in the area. In terms of total revenue, chemicals and petrochemicals lead all sector categories, including major ethylene and polyethylene operations. In addition, machinery, wood and cabinetry manufacturers diversifies the industry base.

Between 1998-2001, key investments in the Red Deer area included an \$843 million investment in the petrochemical sector as part of a larger $\$ 3.3$ billion investment made by Nova Chemicals, BP, and Dow Chemicals. Manufacturing investments totalled $\$ 12.7$ million in central Alberta in 2003, excluding agricultural manufacturing. Investments in agricultural manufacturing include new pork processing facilities and a hay processing plant. ${ }^{61}$ A recent study on investment opportunities for the area identified meat snacks/meal replacements, and protein concentrates for fishmeal substitutes and pet food ingredients as two potential industries for future growth. ${ }^{62}$

\subsubsection{Industry Trends}

\section{Economic Performance}

Alberta has a rapidly growing manufacturing base. Between 1993 and 2003, the industry's shipments increased $123 \%$. Manufacturing shipments were almost $5 \%$ higher in 2003 than 2002, reaching $\$ 45.8$ billion dollars. ${ }^{63}$ Figure 2-5 details the distribution of the manufacturing industry in Alberta in 2003.

Figure 2-5

Distribution of Alberta's Manufacturing Industry (2003)

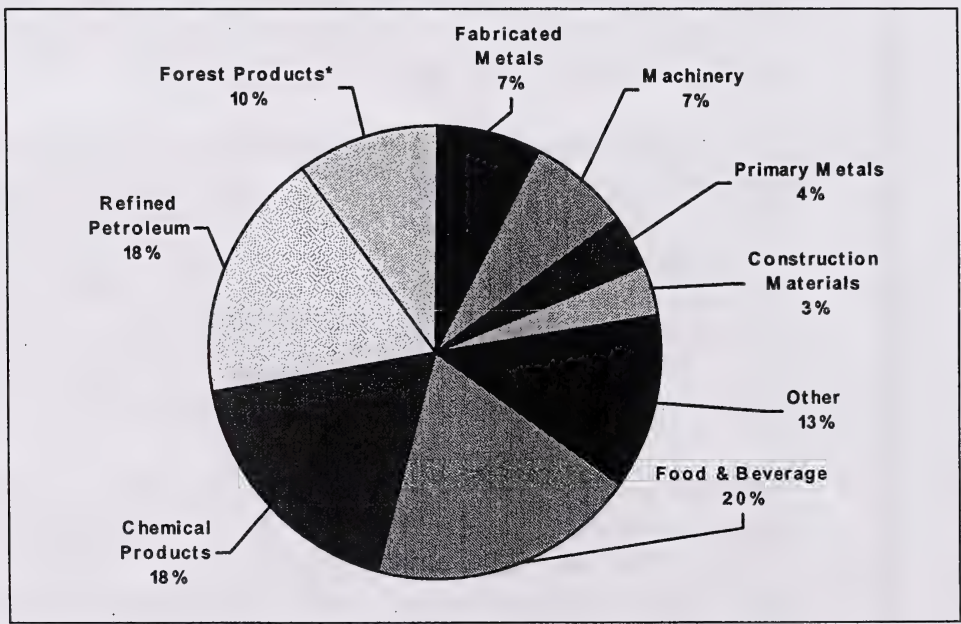

*Includes wood and pulp \& paper industries

Source: Statistics Canada

${ }^{61}$ Source: The 2003 Red Deer Manufacturing Survey, published by the City of Red Deer Land \& Economic Development Department.

${ }^{62}$ T.J. McCann \& Associates, Toma \& Borna Management Consultants, S.J. Campbell Investments Ltd. 2003. Central Alberta Investment Opportunity Study.

${ }^{63}$ Alberta Advantage Website http://www.alberta-canada.com/economy/ecores.cfm (26 Nov. 2004) 
Alberta's manufacturing sector has strengthened in 2004, despite the appreciation of the Canadian dollar. Between January and June, manufacturing shipments increased by $11.2 \%$, twice the growth rate for Canada. ${ }^{64}$ By September, the value of manufacturing shipments had increased $14 \%$ for the first three quarters of 2004 from the same period the previous year. In September alone, manufacturing shipments increased by $20 \%$ from the same month in $2003 .^{65}$

Strong export growth in manufacturing should make a positive contribution to the stability of Alberta's economy. For example, manufacturing exports increased from $3.8 \%$ to $5.9 \%$ of Alberta's exports between 1993 and 2003. Much of this growth was the result of free trade agreements between the U.S. and Mexico, and to a lesser extent with Chile, Costa Rica, and Israel. ${ }^{66}$ Volume and price increases in resource-based industries also served to increase the value of manufacturing shipments in 2004.

Up until June 2004, industries experiencing the strongest growth were machinery $(+21.8 \%)$, electrical equipment $(+24.7 \%)$ and wood products $(+45.1 \%){ }^{67}$ In September 2004 , shipments of primary metals increased by $42 \%$ from the same month in 2003 , chemicals and chemical products increased $34 \%$, and petroleum and coal products also increased by $34 \%$. Growth could be attributed primarily to volume and price increases in several resource-based industries. ${ }^{68}$

Agri-food exports increased from $\$ 4.8$ billion in 1992 to $\$ 9.9$ billion in 2001.

\section{Agri-Food (Food and Beverage)}

Agri-food exports increased from $\$ 4.8$ billion in 1992 to $\$ 9.9$ billion in 2001. In 2002, exports were slightly lower at $\$ 9.8$ billion, which was due to severe drought conditions in the province and low crop supplies.

Alberta's food and beverage processing industries represent the province's largest manufacturing sector, accounting for $24 \%$ of the total manufactured goods in 2002 . Alberta is the third largest food and beverage producing province in Canada. Alberta also represents about $20 \%$ of Canada's total agri-food exports, and is the second largest agri-food exporter in the country after Ontario. The two largest beef slaughtering plants in Alberta are found within the SAL region in High River and Brooks.

\section{Petrochemicals}

Alberta's petrochemical industry is one of its largest manufacturing industries. Twelve major facilities produce ammonia, methanol, ethylene glycol, alpha olefins, nitrogen/oxygen, or ammonium nitrate. ${ }^{69}$ One of North America's largest petrochemical manufacturing complexes is located at Joffre, east of Red Deer. The facility produces ethylene, polyethylene and other products, and is currently the largest ethylene production site in North America. ${ }^{70}$ In 2003, Alberta's petrochemical industry manufactured $\$ 8.3$ billion in products. Exports totaled $\$ 3.6$ billion, with $83 \%$ destined to the U.S. market. Altogether, $\$ 3.5$ billion has been invested in the industry in the last 10 years. $^{71}$

\footnotetext{
${ }^{64}$ Alberta Government. Economic Update, October 2004.

${ }^{65}$ Alberta Canada Website http://www.alberta-canada.com/statpub/pdf/weh nov19.pdf (26 Nov. 2004)

${ }^{66}$ Western Centre for Economic Research. 2004. "Alberta's and western Canada's exports: 15 years of free trade agreements." Information bulletin \#80.

${ }^{67}$ Alberta Government. Economic Update, October 2004.

${ }^{68}$ Alberta Canada Website http://www.alberta-canada.com/statpub/pdf/weh_nov19.pdf (26 Nov. 2004)

${ }^{69}$ Alberta Department of Energy PowerPoint Draft Presentation. 2003. SARS Sector Overview

${ }^{70}$ Nova Chemicals Website http://www.novachem.com/03 locations/03 m joffre.html (26 Nov. 2004)

${ }^{71}$ Alberta Energy Website www.energy.gov.ab.ca/cmn/docs/Alberta_Energy Overview 2004.pdf (26 Nov. 2004)
} 
The competitive advantage of the petrochemical industry's ethane-based production in Alberta has been built upon abundant and relatively cheap supplies of natural gas. The continued viability of the petrochemical industry is contingent upon access to a longterm secure supply of feedstock, availability of natural gas at competitive pricing, and an ability to access global markets. ${ }^{72}$ When natural gas prices in North America hit unprecedented levels in 2000, profit margins disappeared. The price of natural gas quadrupled from around $\$ 2$ per million $\mathrm{Btu}^{*}$ in early 2000 to around $\$ 8$ per million Btu in the beginning of 2001. During this time, ethylene price increases were not able to offset rising feedstock costs, forcing some ethane-based ethylene plants in North America to close down. Further aggravating the situation was a sharp slowdown in ethylene demand in the second half of 2000 while new ethylene production capacity increased. In 2003, natural gas prices in North America increased again, ranging from $\$ 4.5$ to $\$ 5.4$ per million Btu, which resulted in high fuel and ethane feed stock prices, and affected Alberta's ethane-based ethylene producers. ${ }^{73}$

\section{Value-Added Wood and Building Products}

Alberta's building products industry is one of the largest in the province, with production valued at $\$ 6.3$ billion, and exports reaching $\$ 1.9$ billion in 2001 . The industry includes wood-based products, and products made from concrete, steel, and plastic. Value-added building products include prefabricated homes, doors, windows, kitchen and bathroom cabinets, roofing products, and insulation.

Over $90 \%$ of Alberta's exports are to the U.S. market. There are approximately 1200 manufacturers of building products in Alberta, employing over 36,000 people. The industry is composed of many small- to medium-sized firms, with $90 \%$ of companies generating revenues of $\$ 10$ million or less, and $46 \%$ of companies with revenues of $\$ 1$ million or less. The strength witnessed in wood products is in part driven by Alberta's strong performance in housing starts, and the growing renovation market.

\section{Industrial Machinery, Equipment and Fabricated Metals}

This sector accounted for $23.7 \%$ of overall manufacturing employment. The industrial machinery and equipment manufacturing industry is dominated by small- to mediumsized firms with an average of 20 to 25 employees. Businesses manufacture equipment and machinery for agriculture, oil and gas, transportation, electrical and electronics industries. Technology and product development for oil and gas equipment manufactured in Alberta has become the most important resource for the over 1500 companies operating within this sector.

Alberta firms manufacture specialized transportation equipment for the forest industry. For the agricultural industry, transportation equipment manufacturing is primarily focused on supplying the dryland farm operation in Western Canada and Northern U.S. Sales of Alberta-made agricultural equipment, attachments, and farm equipment exceeds $\$ 600$ million annually, about half of which is for export. Alberta companies have also developed niche markets in emergency transportation equipment and specialty trailer manufacturing markets. $^{74}$

The fabricated/primary metal industry has a firm foundation producing products for the forestry, agriculture, mining, and oil and gas sectors in Alberta. Products made in

\footnotetext{
${ }^{72}$ Alberta Energy Website http://www.energy.gov.ab.ca/com/Petchem/Introduction/Petrochemicals.htm (01 Dec. 2004)

"British Thermal Unit

${ }^{73}$ SRI Consulting Website http://ceh.sric.sri.com/Enframe/Report.html?report=360.0000\&show=Abstract.html (01 Dec. 2004)

${ }^{74}$ Alberta Advantage Website http://www.alberta-canada.com/ime/ (01 Dec. 2004)
} 
Over the past ten years, the output of Alberta's high technology sector has more than doubled.
The availability of water is critical to manufacturing activity in the SAL region.
Alberta are essential for resource exploration, development, production and distribution. With growing international competitiveness and high growth in the domestic economy, the outlook for the fabricated/primary metal products industry in Alberta is excellent.

\section{High Technology}

Over the past ten years, the output of Alberta's high technology sector has more than doubled. Today more than 10,000 knowledge-based companies employ 110,000 people and generate annual revenues of approximately $\$ 16$ billion. $^{75}$ Emerging industries include aerospace, biotechnology, and telecommunications equipment manufacturing.

Alberta's aerospace industry is comprised of approximately 60 small- to medium-sized companies, and employs over 4,500 people. The total annual worth of aerospace goods and services produced by Alberta companies was expected to exceed $\$ 675$ million in 2000. The largest companies are involved in the assembly and testing of turbo engines, manufacturing radio handsets and data communications systems for military applications, spare parts manufacturing, and the manufacture of distance measuring equipment and landing systems. Alberta also has considerable expertise in the emerging sub-sector of remotely guided vehicle technologies.

Currently, Alberta has about 40 biotechnology/pharmaceutical companies employing over 3000 individuals. Manufactured products include cattle embryo production, highvalue recombinant proteins, and custom manufacturing for the biotechnology and pharmaceutical industries. These companies are expanding and forming strategic alliances with international firms. Alberta is also home to an increasing number of newer companies including those involved with developments in environmentally friendly technology to treat the liquid effluent from the beef, hog, poultry and fish industries.

\subsubsection{Major Projects}

In Red Deer, Collicut Hanover is in the midst of constructing a \$25 million manufacturing facility. In Calgary, Innicor Subsurface Technologies Inc. completed a \$35 million manufacturing and office facility in 2004.

\subsubsection{Industry Forecasts}

The health of the manufacturing sector in Alberta is dependent upon continued and expanding access to North American and global markets. Continued strong global demand, especially from emerging markets in China and India should serve to positively influence the sector. Alternatively, further weakness of the U.S. dollar will dampen demand for exports south of the border. Integral to this prosperity are continued improvements in production efficiency through industry consolidation, the use of alliances and value-chains, and ensuring long-term supply through stringent resource management practices.

The availability of water is critical to manufacturing activity in the SAL region. Although most of southern Alberta draws upon surface water resources, the Calgary area is starting to draw more groundwater resources, some of it to support manufacturing industries. In southern Alberta, the most intensive industrial use for water is in the food manufacturing sector.

\footnotetext{
${ }^{75}$ Alberta Advantage Website http://www.alberta-canada.com/invest/diveco.cfm (01 Dec. 2004)
} 
As a distribution hub, Calgary is comprised of strong segments in wholesale trade, air, rail and truck transportation.

\subsection{Alberta's Services Sector}

\subsubsection{Industry Overview}

The services sector within the SAL region is diverse, with the private sector and municipal, provincial, and federal governments all key stakeholders in the development and economic strength of the region's physical and social infrastructure. As the economic centre of the region, Calgary offers world-class transportation, finance, health, education, business, and communications services.

Additional strengths of the sector include its access to export markets through an exceptional transportation infrastructure; post-secondary educational facilities, which provide skilled labour to the region; Calgary's strength in attracting head offices of major corporations; provision of health services; and medical research infrastructure.

\subsubsection{Transportation}

As a distribution hub, Calgary is comprised of strong segments in wholesale trade, air, rail and truck transportation. The city has the potential to grow into a major multimodal "Super Hub" for the west, competing with Salt Lake City, Minneapolis, and Vancouver. This sector has been growing at a rate of $5.0 \%$ over the past ten years, far above the North American average growth of $1.8 \%{ }^{76}$

Calgary is located on the main Canadian Pacific Rail (CPR) line, which provides direct container shipment via Vancouver. The TransCanada highway runs through Calgary allowing for access to both Eastern Canada and the Pacific Coast via train and car. With rail links to all of North America through CPR and Canadian National Railway, Calgary's rail system links to all Pacific Coast ports. CPR's head office is in Calgary and recent upgrades by CPR to its Rogers Pass line allows 24 trains to cross the Continental Divide daily, an increase of nine trains per day. ${ }^{77}$

The aviation sector plays a crucial role in providing fast and reliable transportation. Business travel and tourism require high-quality passenger services. Alberta Transportation works to influence federal policy on passenger, shipper and carrier issues regarding competition, pricing, and accessibility ${ }^{78}$ Bringing international air services under the General Agreement on Trade in Services (GATS), together with specialty air services and business aviation, would contribute to the prosperity of the province. However, the current air-bilateral system is restrictive. ${ }^{79}$

The international distribution infrastructure in Calgary, through the use of trucks, brokers, and custom agents has grown into a strong and stable network. Intermodal trucking terminals in Calgary, and Butte, Montana, allow for deliveries of full load shipments between Alberta and California in 48 and 72 hours. Cost-effective truck services extend as far south as Mexico and east into Chicago and the mid-west. Alberta Transportation is currently upgrading the North-South Trade Corridor from the U.S.

\footnotetext{
${ }^{76}$ The Calgary Advantage Website. http://www.calgaryadvantages.com/pdf/calgary business_and industry.pdf (09 Dec. 2004)

${ }^{77}$ Infoport Website. http://www.infoport.ca/bins/content_page.asp?cid=330-339-493 (09 Dec. 2004)

${ }_{78}^{78}$ Alberta Transportation Website. http://www.trans.gov.ab.ca/Content/doctype54/production/pol290.htm (09 Dec. 2004)

${ }^{79}$ Alberta Transportation Website.http://www.trans.gov.ab.ca/Content/doctype54/production/AirGATS.pdf (09 Dec. 2004)
} 


\section{Alberta}

\section{Transportation}

initiated a project to study the needs and develop plans for advanced transportation technologies along the Highway 2 corridor between Edmonton and Calgary.
Talgary is the anking centre of Vestern Canada, vith all of Canada's najor banks raintaining their Western Canadian head offices in Calgary.
Border in the south to west of Grande Prairie in the northwest. In the Lethbridge area, this includes upgrades to Highways 3 and 4 to a multi-lane divided expressway, prior to the development of a multi lane divided freeway. ${ }^{80}$

Alberta Transportation has developed the Strategic Plan for Highway 2 between Edmonton and Calgary as a priority corridor to serve as a testbed for Intelligent Transportation Systems (ITS) initiatives. The ITS Blueprint for this corridor sets out the direction, pace and priorities of investments in the application of "smart" roadway technology. These technologies are potential tools to help monitor and manage traffic flow, detect and clear incidents and provide travelers with real-time information on traffic congestion and road conditions. The ITS Blueprint requires an estimated capital investment of $\$ 21$ million dollars over the next 5 years. Due to the significant role of Highway 2 in the provincial highway network, and as a key link in the CANAMEX North South Trade Corridor, the ITS Blueprint is considered to be a high priority in maintaining Alberta's long-term economic viability. ${ }^{81}$

The Transportation Project Office (TPO) is a public-private partnership that manages some of Calgary's major transportation infrastructure projects, including light rail transit (LRT) extensions, road interchanges, and transit-friendly development of City-owned lands, especially at LRT stations. TPO received a mandate to manage some of the City's major transportation projects to 2007, including LRT extensions, interchanges and development of transportation lands, particularly at LRT stations. Over the past five years, however, Calgary's population has increased significantly. An estimated $\$ 4$ to $\$ 5$ billion will be required over the next 20 years to improve Calgary's transportation system in order to reduce traffic congestion and commuter delays. TPO is currently responsible for projects valued at $\$ 610$ million. $^{82}$

\subsubsection{Finance}

The financial services industry in the SAL region includes multinational and retail banks, investment firms, stockbrokers, trust companies, credit unions, mortgage companies and insurance companies, agents, brokers and adjusters. Calgary is the banking center of Western Canada, with all of Canada's major banks maintaining their Western Canadian head offices in Calgary. ${ }^{83}$.

The financial services sector is highly competitive. Many of the historical barriers prohibiting financial institutions from competing in each other's business have disappeared over the past 15 years. Recent changes to federal law and regulation have opened up new opportunities for foreign banks to operate in Canada, encouraged the start up of new banks with new ownership rules, and given certain non-bank financial institutions direct access to the payments system. Technological innovation has also enabled financial institutions the ability to offer more products and services. In addition to competing private sector institutions, numerous government agencies also offer financial services. Provincial government savings and lending agencies include Alberta Treasury Branches and Alberta's Agricultural Financial Services Corporation. ${ }^{84}$

\footnotetext{
${ }^{80}$ Alberta Transportation Website. http://www.trans.gov.ab.ca/Publications/TransportationPlans.asp (09 Dec. 2004)

${ }^{81}$ Alberta Transportation Website. http://www.trans.gov.ab.ca/Content/docType255/Production/Hwy2SumRprt.pdf (09 Dec. 2004)

${ }^{82}$ Calgary Transportation Project Office Website. http://www.calgarytpo.com/default.asp?action=article\&ID=23 (09 Dec. 2004)

${ }^{83}$ The Calgary Advantage Website. http://www.calgaryadvantages.com/pdf/calgary_business_and_industry.pdf (09 Dec. 2004)

${ }^{84}$ Canadian Bankers Association Website. http://www.cba.ca/en/viewDocument.asp?fl=6\&sl=111\&tl=\&docid=451\&pg=1 (13 Dec. 2004)
} 
Particularly important to the agricultural sector, the Agriculture Financial Services Corporation (AFSC) provides farm loans for beginning and developing farmers, farm income disaster relief, crop and hail insurance, and commercial financing for Alberta's agri-food industries and rural or urban small businesses. The AFSC is the agency responsible for administering the Canadian Agricultural Income Stabilization (CAIS) Program in Alberta. The CAIS Program is designed to provide stabilization funds for farmers, and helps producers protect their farming operations from drops in income. ${ }^{85}$

Between April 1 and September 30, 2004, AFSC advanced more than $\$ 18.7$ million through 175 loans, of which 134 were beef industry related. Two additional Alberta farm loan programs have also been made more flexible to accommodate producers that continue to be affected from BSE related border closures; the Alberta Disaster Assistance Loan Program (ADALP) and the Alberta Farm Development Loan (AFDL) Program. $^{86}$

\subsubsection{Business and Communications}

The business services industry includes law firms, accountants, consultants, graphic designers and advertising firms. This industry has grown in the Calgary region due to the increasing concentration of head offices in the city. ${ }^{87}$ For the Calgary region, there were 82,500 people employed in business services in the year 2000, up from 59,400 in $1996 .^{88}$

The wireless and telecommunications industry employs over 10,000 people in the Calgary region.
The wireless and telecommunications industry employs over 10,000 people in the Calgary region and has three strong segments: Personal Area Networks, Wireless Local Area Networks and Fixed Wireless Access Systems. Calgary is growing at over five times the average growth rate of other regions in this area. ${ }^{89}$ The information technology industry employs almost 23,000 people, mostly in software and system design, Calgary's Information Technology sector growth has exceeded the ten-year North American average.

A landmark development for the communications services industry is the Alberta government's SuperNet initiative. This initiative is set to provide the SAL region with one of the highest rates of Internet connectivity in the world, providing schools, hospitals, libraries, provincial and municipal government offices with access services and programs more effectively and efficiently throughout the province. Construction of over 13,500 kilometres of fibre-optic and wireless connectivity throughout Alberta is in the final stages of completion. ${ }^{90}$

\footnotetext{
${ }^{85}$ Alberta Government Website. http://www.gov.ab.ca/acn/200410/172444E0CF41C-F7A5-4B0E91E194D86D0CA0C1.html (13 Dec. 2004)

${ }^{86}$ Alberta Government Website. http://www.gov.ab.ca/acn/200410/172452D3F5D37-4C58-4577B0951F1671D93BA4.html (13 Dec. 2004)

${ }^{87}$ Calgary Advantages Website. http://www.calgaryadvantages.com/pdf/calgary business and industry.pdf (14 Dec. 2004)

${ }^{88}$ Calgary Advantages Website. http://www.calgaryadvantages.com/htdocs/key industries/business services/index.html (14 Dec. 2004)

${ }^{89}$ Calgary Advantages Website. $\mathrm{http}: / / \mathrm{www} . c a l g a r y a d v a n t a g e s . c o m / h t d o c s /$ key industries/wireless and telecommunications/index.html (14 Dec. 2004)

${ }_{90}$ Alberta SuperNet Website. http://www.albertasupernet.ca/ (14 Dec. 2004)
} 


\subsubsection{Health}

The SuperNet initiative is set to provide the $S A L$ region with one of the highest rates of Internet connectivity in the world

One of two universities in the $S A L$ region, the University of Calgary is one of Canada's premiere research-based universities, receiving more than $\$ 65$ million per year in externallv funded
Under Canada's policy of providing universal coverage for medically necessary health care services, most health care services are covered by federal and provincial taxes. ${ }^{91}$ However, it is the responsibility of each individual province or territory to manage and deliver health services. There are five Regional Health Authorities (RHAs) within the SAL region; the Chinook, Palliser, Calgary, David Thompson and East Central RHAs. ${ }^{92}$

The University of Calgary houses a major medical research centre, where specialty and high-technology care is available at any of the affiliated teaching hospitals within the Calgary Health Region, including the Alberta Children's Hospital, the Peter Lougheed Hospital, the Foothills Hospital and the Rockyview Hospital. In addition, selective rotations occur at other locations in southern Alberta. ${ }^{93}$

The Alberta Heritage Foundation for Medical Research is a government-funded body founded in 1980 for the purposes of funding biomedical and health research at universities and research institutes in Alberta. The government offered an initial $\$ 300$ million towards the foundation and since its inception, more than $\$ 600$ million has been given to the scientific community.

\subsubsection{Education}

Public, Catholic and other private schools in Alberta operate under regional school boards. Students in K-12 consistently score among the highest on achievement tests in Canada and North America, with grade nine student achievement particularly strong in the areas of math and science. ${ }^{94}$ There are 19 public, private and religious postsecondary institutions within the SAL region, many of which are located in Calgary, and others located in Camrose, Lacombe, Red Deer, Lethbridge, and Medicine Hat.

The University of Calgary, one of two universities located in the SAL region, is one of Canada's premiere research-based universities, receiving more than $\$ 65$ million per year in externally funded research. The University has a full-time student population of approximately 22,200 , with 16 faculties and in excess of 60 academic departments and major programs. ${ }^{95}$

The Southern Alberta Institute of Technology (SAIT) offers four applied degrees, 72 certificate and diploma programs and training in 25 pre-employment and apprenticeship trades. Nearly 70,000 individuals were trained at SAIT in 2000, and the institute has doubled its enrollment in the last five years. Mount Royal College is home to the Mount Royal Music Conservatory, the second largest music conservatory in Canada. The college offers community courses, applied degrees and university-accredited courses in arts and sciences. In addition, customized training in Information Technology studies is linked to industry partnerships with major corporations. ${ }^{96}$

\footnotetext{
${ }_{91}^{91}$ Health Canada Website. http://www.hc-sc.gc.ca/english/care/ (14 Dec. 2004)

${ }_{92}$ Alberta Health Website. http://www.health.gov.ab.ca/regions/map lookup.htm (09 Dec. 2004)

${ }^{93}$ Canadian Resident Matching Service Website. http://www.carms.ca/jsp/main.jsp?path=./content/program/university/calgary (09 Dec. 2004)

${ }_{94}$ Infoport Website. http://www.infoport.ca/bins/content page.asp?cid=330-340-491 (09 Dec. 2004)

${ }^{95}$ Calgary Advantages Website. http://www.calgaryadvantages.com/htdocs/who am _international/education/index.html (07 Dec. 2004)

${ }^{96}$ Infoport Website. http://www.infoport.ca/bins/content page.asp?cid=330-340-491 (09 Dec. 2004)
} 


\section{SECTION 3: REGIONAL ECONOMIC CHARACTERISTICS AND TRENDS}

Included in the map below ${ }^{97}$ are southern Alberta's main economic regions, which are discussed in further detail in the sections to follow. The southern Alberta region examined in the study encompasses in whole or in part the following economic regions:

$>$ Calgary Economic Region;

$>$ Red Deer Economic Region;

$>$ Lethbridge-Medicine Hat Economic Region;

$>$ Camrose-Drumheller Economic Region; and

$>$ Banff-Jasper-Rocky Mountain House Economic Region.

Combined, these economic regions represent $35 \%$ of Alberta's land area but contain more than $55 \%$ of the province's total population ${ }^{98}$.

Figure 3-1

Economic Regions of Southern Alberta

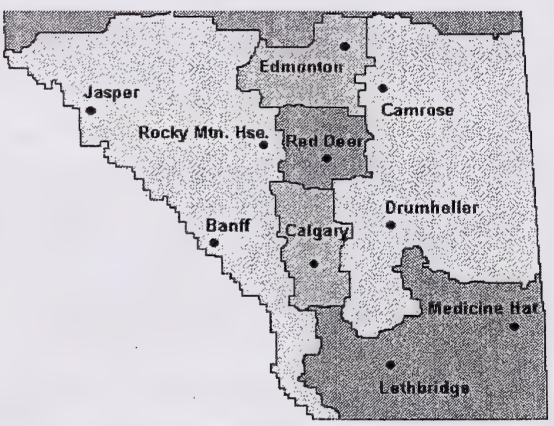

Overall, it is expected that the economy of Alberta will continue to grow, albeit at rates lower than that of the last five years.

\subsection{Overview of Alberta}

The province is expected to show strong growth through to the year $2012 .^{99}$ A high rate of inflation is expected during this time, which will be driven by increasing energy costs. It is also anticipated that inflation and unemployment rates will remain low and the labour market will remain tight. Overall, it is expected that the economy of Alberta will continue to grow, albeit at rates lower than that of the past five years.

\footnotetext{
${ }^{97}$ Source: Alberta Human Resources and Employment

${ }^{98}$ Source: Statistics Canada 2001 Census data

${ }_{99}$ The Centre for Spatial Economics and Alberta Human Resources and Employment. Alberta Regional Occupation Outlook. Edmonton: Alberta Human Resources and Employment, 2002.
} 


\subsection{Economic Outlook for Southern Alberta}

Southern Alberta's employment underscores the region's robust economic growth, but also presents a number of key challenges for sustainable development. In 2003, the largest increases in employment in this region were seen in trade (retail and wholesale); agriculture; forestry, fishing, mining, oil and gas, and public administration. The greatest declines in employment were observed in information, culture and recreation; manufacturing; other services; and educational services ${ }^{100}$.

The combination of rising energy prices and the growth of the service economy has stimulated significant residential and non-residential investment throughout the SAL region. The region has also benefited from a further stimulus in the form of robust population growth and the significant expansion in the size and number of business establishments operating in the southern Alberta region. It should be noted, however, that although southern Alberta has about half of the province's population, recent data (June 2004) suggest that the area constitutes only $17 \%$ of the total major project spending in the province ${ }^{101}$. The massive scale of investment in the Alberta oil sands

The Calgary region is the fastest growing region in southern Alberta. partially explains the limited share of capital investment in the southern Alberta Region.

The Centre for Spatial Economics completed a major economic study of the five economic regions that are located wholly or partly within the SAL region. As detailed in Figure 3-2, four of these regions are expected to experience positive growth during the next 10 years, although the pace of economic expansion will not be uniform across all regions. Forecast data were unavailable for the Banff-Jasper region.

The Calgary Economic Region is projected to be the fastest growing region in southern Alberta ${ }^{102}$ while rural areas in the $S A L$ region are expecting to experience reduced population and economic activity. ${ }^{103}$ As shown in Figure 3-2, growth in Calgary is expected to be the fastest growing region in terms of percent change in GDP, employment, and population.

Figure 3-2

Average Annual Growth - Selected Indicators 2005-2014 - Average Annual Percent Change ${ }^{104}$

\begin{tabular}{|l|c|c|c|}
\hline Economic Region & Real GDP & Employment & Population \\
\hline Calgary & $3.0 \%$ & $1.9 \%$ & $1.8 \%$ \\
\hline Lethbridge-Medicine Hat & $2.5 \%$ & $1.6 \%$ & $1.5 \%$ \\
\hline Camrose-Drumheller & $2.2 \%$ & $1.9 \%$ & $1.3 \%$ \\
\hline Red Deer & $2.3 \%$ & $1.5 \%$ & $1.0 \%$ \\
\hline $\begin{array}{l}\text { Weighted Average - } \\
\text { Southern Alberta Region }\end{array}$ & $\mathbf{2 . 7 \%}$ & $\mathbf{1 . 8} \%$ & $\mathbf{1 . 6 \%}$ \\
\hline
\end{tabular}

${ }^{100}$ Alberta Human Resources and Employment (2004a).

${ }^{101}$ The Inventory of Major Development Projects accounts for all projects planned, underway, or recently completed and valued at or above $\$ 2$ million. Data are for the Red Deer, Calgary, Camrose-Drumheller, and Lethbridge-Medicine Hat Economic Regions.

${ }^{102}$ Global Training, Inc. Southern Alberta Landscapes: Meeting the Challenges Ahead: Social/Economic Aspects. Edmonton: Unpublished Report Prepared for Alberta Environment, 2004.

${ }^{103}$ Global Training, Inc. Southern Alberta Landscapes: Meeting the Challenges Ahead: Social/Economic Aspects. Edmonton: Unpublished Report Prepared for Alberta Environment, 2004.

${ }^{104}$ The Centre for Spatial Economics. Economic Outlook Summary. 2002. 
While the Southern Alberta region is projected to experience relatively high growth during the next ten years, economic growth is expected to moderate over the longer term.
The majority of demographic and economic forecasts produced for the southern Alberta region suggest that the region will continue to enjoy above average population and economic growth.
While the Southern Alberta region is projected to experience relatively high growth during the next ten years, economic growth is expected to moderate over the longer term. Nevertheless, it is expected that real GDP growth in the southern Alberta region will exceed $2.0 \%$ per year over the next 20 years. Refer to Figure 3-3.

Figure 3-3

Growth in Selected Indicators - Years 2005-2014 \& 2015-2024

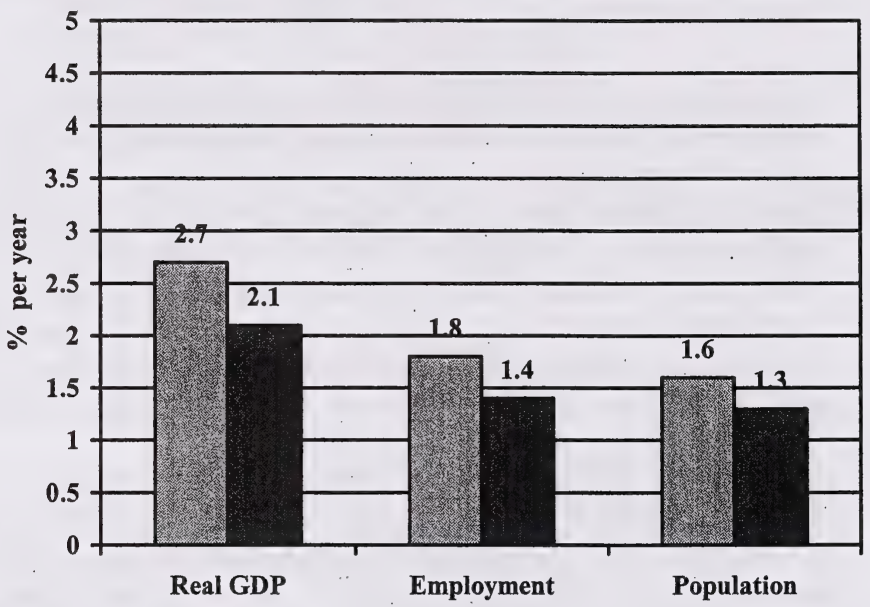

口2005-2014

2015-2024

Source: Centre for Spatial Economics.

Note: Data is weighted by each region's share of GDP, employment and population.

The dichotomy in economic growth between Calgary and other areas in the Southern Alberta region could further exacerbate land pressures in the greater Calgary area. For example, population growth during the next 10 years for the Calgary area (1.8\%/year) will be almost double that of Red Deer (1.0\%/year), and will be much higher than that of Camrose-Drumheller (1.3\%/year). The relatively rapid growth of the Calgary area will further underscore the area's dominance in the Southern Alberta region.

\section{Economic Outlook Summary}

The majority of demographic and economic forecasts produced for the southern Alberta region suggest that the region will continue to enjoy above average population and economic growth. While the Calgary Economic Region is expected to witness the strongest growth, other communities including Red Deer and Lethbridge are also expected to benefit from strong growth. It show be noted, however, that the forecasts are not without "risks" - both upside and downside risks. Upside risks include the continuation of high energy prices; few forecasts have incorporated long-term oil prices above $\$ 30 \mathrm{US} / \mathrm{bbl}$, which is well below the current price of $\$ 45 \mathrm{US} / \mathrm{bbl}$. Maintenance of high oil prices could result in an even greater economic stimulus to the region. On the downside, the region will be subject to possible economic contraction should oil prices decline to below $\$ 25 \mathrm{US} / \mathrm{bbl}$. Similarly, the region's agricultural economy depends on free access to US markets, which could be at risk should trade barriers remain. 
The Calgary region is southern Alberta's major economic hub with almost $70 \%$ of the region's major project spending

Because of slowing major construction projects and decreases in investments, net in migration will see a decline in the latter half of the period to 2009.
Two-thirds of the SAL region's urban population is located in the Calgary metropolitan area $^{105}$ According to AlbertaFirst.com, Calgary has one of Canada's fastest growing populations and is the second largest corporate headquarter centre in Canada ( $89 \%$ of oil and gas producers are headquartered in Calgary). In terms of industry, manufacturing continues to diversify into sectors such as food processing, clothing, furniture, and high technology. For example, annual output from Calgary's advanced technology sectors has quadrupled to $\$ 7$ billion and employment has tripled to 29,000 jobs in the last 16 years. The tourism industry is an opportunity for investment as Calgary is considered the gateway to Banff and Canadian Rockies. According to Alberta Economic Development, over 5.1 million people visited Calgary and area in 2002, generating $\$ 1.06$ billion in consumer spending.

In 2004, the Calgary Economic Region witnessed a decline in the unemployment rate. The housing and condominium market helped to create strong employment levels in construction. The greatest increases in employment were seen in trade; construction; health care and social assistance; and finance, insurance, real estate, and leasing. Offsetting some of these gains, however, were declines in employment in transportation and warehousing; utilities; professional, scientific and technical services; and forestry, fishing, mining, and oil and gas. ${ }^{106}$

The Calgary Economic Region is southern Alberta's major economic hub with almost $70 \%$ of the region's major project spending ${ }^{107}$ and, with a population of over one million, is the largest metropolitan area in the province. According to the Calgary Advantages website ${ }^{108}$ :

- Calgary has enjoyed sustained growth; Calgary's real economy grew by over $25 \%$ between 1997 and 2001;

- The region produces over $\$ 37$ billion in goods and services annually;

- Calgary added 125,000 jobs between 1996 and 2001 - representing an average annual employment growth rate of $5 \%$; and

- Calgary's personal income growth rate also leads the country; the average Calgarian earned 25\% more in 2001 than in 1995.

According to recent short-term socio-economic ${ }^{109}$ and population ${ }^{110}$ outlooks, the following trends are anticipated for Calgary until 2009:

- Calgary's population is expected to grow in the next 5 years, albeit at a slower rate than the last 5 years. However, a large increase in the older population will occur because of services available in the area;

\footnotetext{
${ }^{105}$ Global Training, Inc. Southern Alberta Landscapes: Meeting the Challenges Ahead: Social/Economic Aspects. Edmonton: Unpublished Report Prepared for Alberta Environment, 2004.

${ }^{106}$ Alberta Human Resources and Employment (2004a).

${ }^{107}$ The Centre for Spatial Economics and Alberta Human Resources and Employment. Alberta Regional Occupation Outlook. Edmonton: Alberta Human Resources and Employment, 2002.

$108 \mathrm{http} / /$ calgaryadvantages.com/htdocs/why calgary/economic performance/index.html (11 Jan. 2005)

109 Corporate Studies and Economics. "Calgary's Shifting Socio-Economic Landscape: A Long-Term Forecast of the Economy and Society 2003-2033."

$<$ http://content.calgary.ca/CCA/City+HalVBusiness+Units/Corporate+Studies+and+Economics/Corporate+Economics Forecasting/Calgary+and+Region+Economic+Outlook/Long+Term+Socio+Economic+Outlook/20032033+Long+term+SocioEconomic+Outlook.htm> (26 Nov. 2004).

${ }_{110}$ Economic and Demographic Analysis, Data Development and Evaluation for Alberta Human Resources and Employment. "Alberta Regional Population Outlook 2004-2009." 2004. <http://www3.gov.ab.ca/hre/lmi/pdf/200409_outlook.pdf> (26 Nov. 2004).
} 
- Because of slowing major construction projects and decreases in investments, net in migration from other provinces will see a decline in the latter half of the period;

- Reduced net migration will contribute to an aging population as baby-boomers move into pre-retirement age;

- Increased cost of living will increase demand for childcare, out-of-school care and respite care;

- Aboriginal youth will comprise a growing share of the educational system and labour force over the forecast period;

- Strong employment growth with low unemployment is expected to continue for the forecast period;

- Incomes in Calgary will remain substantially above the national average up until 2009; and

- Declines in the number of people registering for trades and continued increases in the cost of education may challenge the local economy.

The significant increase in the region's total population over the next 20 years will contribute to the considerable stress in managing growth and provision of public services. For example, during the next 20 years, it is estimated that: ${ }^{111}$

$>$ The net increase in the region's population will be more than 424,000 people. This is the equivalent of adding a city the size of Airdrie to Calgary each-year for the next 20 years;

$>$ By 2024, Calgary will have a senior's population in excess of one-quarter million people. The growth in the number of seniors in the region will be four times higher than that of the general population; and

$>$ To accommodate the growth in Calgary's population, it is estimated that an additional 206,000 homes will be required for the City over the next 20 years.

Growth is anticipated for smaller neighbouring cities due to their proximity to Calgary.
In addition, growth is anticipated for smaller neighbouring cities due to their proximity to Calgary. For example, Airdrie's population is expected to increase from 19,852 in 2001 to 65,852 by $2031 .^{112}$

Many of the key informants interviewed for this project were of the opinion that Calgary would continue to witness strong growth in the foreseeable future. The combination of high world energy prices and the combined expansion of Calgary as Western Canada's corporate headquarters, were seen as key catalysts for the future growth in the region. Key informants noted that such growth would not be without consequences, as the region would face several challenges, including:

$>$ Lack of skilled trades and/or workers with the required skills to support new head office and knowledge-based functions;

$>$ Management of urban sprawl and the competition for land and water resources among neighbouring agriculturally-based jurisdictions; and

$>$ Extensive reliance on the oil and gas sector, which could continue to result in "boom and bust" cycles for the region.

111 Source: Centre for Spatial Economics. Economic Outlook Summary, 2002.

${ }^{112}$ Brown \& Associates Planning Group, Prepared in Conjunction with D.A. Watt Consulting Group Ltd. and Clayton Research Associates Ltd. City of Airdrie Growth Study 2000. Airdrie: City of Airdrie, 2001. 


\subsection{Red Deer Economic Region}

In 2004 , the Red Deer region had a population of 166,100 . In contrast to many other Southern Alberta regions, Red Deer is projected to experience relatively stable growth during the next 20 years, as population growth will average $1.0 \%$ per year during this time. Growth in population for the period from 2005 to 2014 (1.0\%) will be very similar to that of the period from 2015 to 2024 (0.9\%).

Given the relatively diversified nature of the region's economy, Red Deer will not likely see the economic "extremes" as witnessed in the Calgary region. For example, the region's diversified economic base, such as those relying on agriculture, food processing and light manufacturing, will result in the region experiencing more stable growth relative to regions that have higher dependencies on oil and gas exploration and extraction.

Overall, real GDP growth in the Red Deer region is forecast to be approximately $2.0 \%$ per year over the next 20 years.

\section{Economic} projections for the LethbridgeMedicine Hat Economic region suggest that the region will witness uneven economic growth during the next 20 years.
Overall, real GDP growth in the Red Deer region is forecast to be approximately $2.0 \%$ per year over the next 20 years. Such growth will be sustained by Red Deer's position in the middle of the Calgary-Edmonton corridor. However, key informants identified several possible economic threats to the region. Among these include the following:

$>$ Excessive reliance/concentration on oil and gas development to the detriment of economic development in other sectors;

$>$ Lack of information as the key business "drivers" of the region - the lack of information has hindered the ability of the region to develop an effective economic development strategy; and

$>$ Limited ability to attract new businesses due to community reaction/acceptance of such development.

Overall, key informants were of the opinion that the long-term growth of the region would hinge on better information/sharing/collaboration between the various levels of government and municipalities, promotion of industrial diversification in the region, and the ability of the region to effectively manage the existing renewable (i.e. water) and non-renewable (i.e. oil and gas) resources in the region.

\subsection{Lethbridge-Medicine Hat Economic Region}

The Lethbridge-Medicine Hat Economic region is the second largest region in the southern Alberta area. With a population of 261,100 in 2004 , the region has a considerable economic base, including agriculture, service industries, and manufacturing. The region had the highest labour force growth rate in Alberta over 2003 , along with a $1.0 \%$ decrease in its unemployment rate. Employment increases were greatest in manufacturing; trade; health care and social assistance; and information, culture and recreation. Utilities; construction; other services; and professional, scientific and technical services saw the largest declines in employment numbers ${ }^{113}$.

Economic projections completed for the region suggest that the region will witness uneven economic growth during the next 20 years, as real GDP growth in the last half of the forecast period (1.7\%/year between 2015-2024), will be considerably lower than the

${ }^{113}$ Alberta Human Resources and Employment (2004a). 
The Camrose-

Drumheller region

has a population of

190,000 (2004)

and is projected to

experience

relatively high

stable population

growth (1.3\%/year)

during the next 20

years. economic growth for the next ten years (2.5\%/year between 2005-2014).

Notwithstanding the significant fluctuation in economic activity, population growth is expected to be relatively robust - averaging $1.3 \%$ per year over the next 20 years.

Agriculture plays a key role in the retail, wholesale, and service sectors of the cities of Lethbridge and Medicine Hat. Irrigation is vital to the area and hundreds of millions of dollars of investments have been made to maintain a sustainable water delivery infrastructure that supplies water for irrigation. ${ }^{114}$ In addition to agriculture, manufacturing and food processing are also important to the region, as is its expanding retail sector. Canadian Forces Base Suffield also pays an influential role, contributing $\$ 120$ million per year to the local economy.

As noted by one key informant working in the Lethbridge and Palliser regions, the main strengths are the region's natural resources, low cost business environment, and its irrigation system. In terms of weaknesses and threats to the region, labour shortages were a primary concern and it was felt there were insufficient post-secondary opportunities. When asked what they thought of future economic growth for the region, informants listed the BSE trade barrier, the fluctuating price of natural gas, and the migration of retirees into the urban community as having the greatest impact on development.

\subsection{Camrose-Drumheller Economic Region}

The Camrose-Drumheller Economic Region has a population of 190,000 (2004) and is projected to experience relatively high stable population growth $(1.3 \% /$ year $)$ during the next 20 years. At $4.0 \%$, this region had the lowest unemployment rate in the province in 2003, with construction in Drumheller providing the greatest increase in employment. Employment grew most in educational services; business, building and other support services; finance, insurance, real estate and leasing; and forestry, fishing, mining, oil and gas. The largest declines were in construction; manufacturing; trade; and transportation and warehousing ${ }^{115}$.

Key informants provided insight as to the key economic opportunities and challenges facing the region. In general, individuals felt that the access to affordable land for development (relatively inexpensive compared to Calgary) would contribute to economic development and expansion in the region. Furthermore, local government support for development is also seen as a strength of the region. The proximity of many of the region's towns and cities to the Calgary region was seen as both a strength and a challenge to growth. While the Camrose-Drumheller area has benefited from the "spillover" from Calgary to neighbouring areas, other rural centres have witnessed outmigration of youth from rural town to the Calgary area. The out-migration of youth was seen to have major ramifications in terms of the long-term growth of rural areas.

Overall, it is forecasted that the region's economy will grow by $1.8 \%$ per year during the next 20 years. Economic growth will not be uniform as growth during the next ten years (2.2\%/year between 2005-2014) will be markedly higher than that of the latter half of the forecast period (1.5\%/year between 2015-2024). Uneven economic growth will also

\footnotetext{
${ }^{114}$ Alberta First. "Community Profiles." 2004. <http://www.albertafirst.com/profiles/> (26 Nov. 2004).

${ }^{115}$ Alberta Human Resources and Employment (2004a).
} 
affect employment growth, as the rate of increase in employment is expected to decline from 1.9\%/year (2005-2014) to 1.2\%/year for the period from 2015 to 2024 .

Long-term development of the region will be influenced by several external factors, including the maintenance of a strong, vibrant tourism industry, the resolution of trade issues (BSE in particular) with the United States, and continued development of the oil and gas sector.

\subsection{Banff-Jasper-Rocky Mountain House Economic Region}

Over the period of 2004-2009, it's expected that the Banff-JasperRocky Mountain House Economic Region's GDP will grow by $2.1 \%$ annually - lower than the provincial average of $3.2 \%$.

The major economic base of the region is oil and gas, forestry, tourism and agriculture. The Banff-Jasper-Rocky Mountain House Economic Region was the only region in Alberta to experience a decline in its labour force, which decreased by $6.5 \%$, or 3,200 people, in 2003. The Town of Banff reported a population of 8,282 in 2003 and experienced a $26.7 \%$ increase in its population between 1996 and 2001 . Industries in this region with the highest increases in employment were finance, insurance, real estate, and leasing. The information, culture, and recreation industry, along with the forestry, fishing, mining, and oil and gas industries all experienced decreases in employment over the previous year. ${ }^{116}$

Over the period of 2004-2009, it's expected that the region's GDP will grow by $2.1 \%$ annually. This is lower than the provincial average of $3.2 \%$ and the national average of $3.1 \%$ annually. However, the Accommodation and Food Services industry is driven by a strong tourism industry and will average the highest percentage of GDP growth during the forecast period at $3.4 \%$ annually ${ }^{117}$.

Employment is expected to grow at an average of $2.0 \%$ over the forecast period, due largely in part to the Accommodation and Food Services industry. In addition, "the region's unemployment rate is expected to remain quite stable and will average $4.7 \%$."118

Not unlike the Camrose-Drumheller Economic Region, future economic growth for the region will be dependent in part to a strong tourism industry and a sustained oil and gas industry.

\footnotetext{
${ }^{116}$ Alberta Human Resources and Employment (2004a).

${ }^{117}$ Alberta Human Resources and Employment. "Alberta Regional Occupation Outlook:2004-2009, Banff-Jasper-Rocky Mountain House Economic Region Summary Report". 2004, October. $<$ www3.gov.ab.ca/hre/lmi/pdf/occ/_forecast_Banff.pdf> (10 Jan. 2004).

${ }^{118}$ Alberta Human Resources and Employment. "Alberta Regional Occupation Outlook:2004-2009, Banff-Jasper-Rocky Mountain House Economic Region Summary Report”. 2004, October. $<$ www3.gov.ab.ca/hre//mi/pdf/occ/_forecast_Banff.pdf> (10 Jan. 2004).
} 


\section{SECTION 4: CHALLENGES AND BARRIERS TO ECONOMIC GROWTH}

The production of natural gas, a key industry for southern Alberta, could face a number of challenges, such as environmental regulation (i.e. the Kyoto Protocol) and increased cost of production.

\subsection{The Energy Sector}

The Public Policy Forum, an organization aimed at improving the quality of government in Canada which partners business, federal/provincial governments, the voluntary sector, and the labour movement, held a conference in mid-2003 titled Building the West for the $21^{\text {st }}$ Century.

One of the key conclusions from the conference was related to energy: "The energy sector remains the key driver of the Western Economy but experiences new challenges." 119 These challenges vary, ranging from harmonization of federal and provincial economic regulations, to Aboriginal issues, to market competitiveness. The production of natural gas, for example, a key industry for southern Alberta, could face a number of challenges, such as environmental regulation (i.e. the Kyoto Protocol) and increased cost of production. In light of these challenges, some panelists emphasized the need for the government to recognize the limits of economic growth and develop a long-term strategic energy plan. It was also noted during the forum that "new ecofriendly technologies (e.g. hydrogen technology and carbon dioxide sequestration) have the potential to build economic advantage and reduce costs."

Information collected from key informants has indicated that there are several potential weaknesses and threats to the energy sector, which range from public perceptions of the industry to governmental regulations and policies to status of international markets. Specific examples include the following:

- Public perception that oil and gas development cannot occur without minimal impact to the environment and to public health and safety;

- International markets and suppliers, price volatility added costs of cumulative effects assessments;

- Provincial and federal regulations and policies (e.g., Kyoto Protocol);

- Declining conventional reserves are driving the industry into new regions, which could lead to increased competition for land among users;

- Increasing public opposition to energy development in environmentally sensitive areas or near human settlements; and

- Public perception towards energy development and lack of understanding of the social and economic benefits afforded to Albertans from energy development.

Among key informants, access to land and water for oil and gas development was cited most often as potential threats and barriers to growth for their industry. For example, it was reported that urban expansion and public resistance to development could limit land accessibility. Competition for water between industries and with urban areas was viewed as another potential threat to the industry.

119 The Public Policy Forum. "Building the West for the $21^{\text {st }}$ Century: A Conference on Economic Transformation in Western Canada: May 5 \& 6, 2003". 2003.

http://www.ppforum.com/ow/economic transform_WC/Building_West 21st_Century Summary.pdf. (07 Sept. 2004) 
Additional comments regarding potential threats and barriers to growth for the energy sector provided by key informants included the following:

- The transmission system currently in place is unable to accommodate input from all sources of electrical power generation;

- There is the potential for an over-supply of electrical power into the system, which may result in lowering of prices ${ }^{120}$;

- Accessibility to markets within North America;

- Increased value of the Canadian dollar;

- Issues in the Middle East (e.g. terrorism) and threats to oil supplies; and

- A shortage of skilled labour.

\subsection{The Agriculture Sector}

Additional conclusions made by The Public Policy Forum related to agriculture, another crucial player in the southern Alberta economy, accounting for $13 \%-16 \%$ of the labour force in the region. ${ }^{121}$ Issues related to farming technologies and practices, international trade, and the continuing trend towards consolidation of smaller farms, will play a key part in the sustainable development of southern Alberta. It was suggested, "The agricultural sector is adjusting to structural changes and must add value to what it produces." 122

Issues related to farming technologies and practices, international trade, and the continuing trend towards consolidation of smaller farms, will play a key part in the sustainable development of southern Alberta.
Key informants reported several potential weaknesses and threats to the agriculture industry, of which the predominant concern was access to water and uncertainty regarding water allocation in the future. Other top concerns included market access and international trade issues (i.e. food safety and quality issues), and community reluctance for feedlots/packing plants in their area. Further examples of potential weaknesses and threats included the following:

- Climate change/droughts; variability in rainfall;

- Susceptibility to changes in commodity prices and currency fluctuations;

- Globalization of food supply chain may affect ability to be competitive on the global market;

- Urban encroachment/sprawl and other competition for agricultural land;

- Competition for skilled labour with other sectors such as oil and gas, and rural vs. urban areas; and

- Farm profitability now and for the next generation.

In addition, the following were viewed as potential barriers to growth for the agriculture industry:

- Lack of value placed by society on the industry's operations;

- Economic variability and marketing challenges;

- Increased value of the Canadian dollar.

${ }^{120}$ Lower energy prices would benefit other industries such as agriculture, manufacturing and export industries.

${ }^{121}$ AlbertaFirst.com (2004a, 2004b, 2004c).

${ }^{122}$ Alberta Economic Development. "Fastest Growing Economy" http://www.alberta-canada.com/economy/fgecono.cfm. (07 Sept. 2004) 
The only possibilities for expansion within the industry would be as a result of more intensive land management practices or through incorporating value-added products into their production.
Industrial use is expected to show the greatest increase in water demand, which may result in conflicting demands between agriculture and other users of this limited resource. $^{123}$

Water availability and the allocation of water resources to ensure the long-term sustainability of water supplies is an acute barrier to growth in the industry within much of the SAL region. Areas dependent on irrigation are entering a "demand management phase", in which growth is attainable from increases in efficiency only and not from new water sources. In addition, land access limitations due to urban expansion, competition from other economic sectors, and habitat conservation initiatives could serve to limit growth in the agricultural sector.

\subsection{The Forestry Sector}

A key informant in the forestry industry indicated that a challenge for their industry is the nature of their crop; it takes 100 years to grow to maturity. Consequently, long-term security of their land base is vital to their operations. However, the land allocated must be used in conjunction with other industries.

Also, there is limited opportunity for expansion within their industry as forest resources are currently fully allocated. As a consequence, the only possibilities for expansion within the industry would be as a result of more intensive land management practices or through incorporating value-added products into their production. On the other hand, issues related to exporting to the United States may prove to be a barrier for the industry, particularly in regards to softwood lumber.

According to the research, several weaknesses and threats could prove to challenge the industry, which include:

- Market variability and cyclical nature of demand for their product;

- Limited public knowledge of the industry;

- Government regulations causing increased operating costs;

- Availability of labour;

- Climatic conditions and global warming trends suggests that warmer and drier conditions may lead to an increased number of forest fires;

- Other natural threats such as insects and disease; and

- Appreciation of the Canadian dollar relative to that of the U.S.

\section{Trade Factors}

Since May 22, 2002 most Canadian softwood lumber exported to the US has been subject to a $27 \%$ duty collected by U.S. Customs. A NAFTA panel recently voted unanimously that there was no evidence to support the U.S. International Trade Commission's (ITC) determination that Canadian imports threaten injury to the U.S. lumber industry. However, on November 24, 2004 the U.S. prolonged the dispute by formally requesting that a NAFTA "extraordinary challenge committee" (ECC) review the NAFTA panel decision on threat of injury. ${ }^{124}$ In addition, the industry had expected the U.S. Department of Commerce to cut the $27.2 \%$ combined countervailing and anti-

\footnotetext{
${ }^{123}$ Water for Life Website http://www.waterforlife.gov.ab.ca/ (01 Dec. 2004)

${ }^{124} \mathrm{PRNewswire}$ Website http://www.prnewswire.com/cgi-bin/stories.pl?ACCT=109\&STORY=/www/story/11-242004/0002503547\&EDATE. (23 Nov. 2004).
} 
dumping duties in half after completing a review. On December 15, 2004, the Commerce Department reduced the combined rate to $21.2 \%$ by using a new method of calculating the rate of subsidy Canadian softwood allegedly receives. In response, Canadian forestry executives cancelled a meeting with their American counterparts, which was planned to resume talks regarding settling the longstanding softwood lumber trade dispute. ${ }^{125}$

\subsection{The Tourism Sector}

Growth in Alberta's tourism sector could face some challenges in the future. For example, an article posted by the Alberta Wilderness Association has noted that ecotourism is considered one of the fastest growing sectors in the tourism industry in Alberta, as the province's national and provincial parks contain large undisturbed landscapes. ${ }^{126}$ However, opportunities for ecotourism on public land outside parks may be affected by other users such as forestry and oil and gas, and by unrestricted use of allterrain vehicles. According to one key informant, another challenge for the tourism industry is the strength and success of other sectors in the province. Because of their success, there is not a sense of urgency within the province to develop tourism in the region.

Recently, several events have had negative impact on the tourism industry and, to varying degrees, are potential threats to the industry in the future. Communicable disease outbreaks such as Severe Acute Respiratory Syndrome (SARS), pest-borne viral infections such as West Nile virus, and socio-economic factors including appreciation of the Canadian dollar and terrorist attacks all caused a reduction in international air travel. In addition, the following were noted as potential weaknesses, barriers, or threats of the tourism industry:

- Limits to tourism development opportunities/access to crown land (e.g. Kananaskis Recreation Policy) particularly in the foothills/mountains west of Calgary;

- Lack of policy base supporting new development on crown land;

- Lack of public awareness of many tourism destinations and opportunities (i.e. outside of the national parks);

- Distances between existing resources make short tourism visits difficult;

- Limited air and road access in some areas;

- Availability of water and insufficient management of river flows to facilitate recreational use; and

- Lack of recognition of tourism as legitimate user and partner in the region.

Restricted air and road access to SAL destinations inhibit the region's tourism. Recent air access capacity reductions into Canada and Alberta limit the number of visitors. Improved roads and trails to and within SAL destinations would increase tourism.

The tourism industry requires high quality lands with convenient access in order to develop. Much of Alberta's Crown land with high tourism potential is already under

\footnotetext{
${ }^{125}$ Canadian Broadcasting Corporation Website. http://www.cbc.ca/cp/business/041215/b1215152.html. (17 Dec. 2004)

${ }^{126}$ Marshall, A. "Cloudy Future for Alberta Ecotourism." Wild Lands Advocate 10.3 (2002):1-4

$<$ http://www.albertawilderness.ca/Issues/PLarchive/AR0206WD.pdf $>$ (26 Nov. 2004).
} 
some form of lease, disposition, or protective legislation limiting development. Limits on future accommodation and activity development in National Parks will increase demands on provincial lands, and there are limited product offerings outside of Parks to meet these demands. There are also conflicts between competing recreational user groups; e.g., hiking, biking, equestrian, scenic viewing, and motorized off-road vehicles.

Financing tourism developments is difficult in Alberta for a number of reasons. Lending institutions require higher levels of equity from tourism developers compared to other industries. In addition, timeshares and fractional ownership financing options are not available in Alberta. Development on leased land can reduce startup costs, but financing for developments on leased land is difficult to secure. Furthermore, leases on Crown land are limited to 25 years (compared to 41 or 99 year leases in National Parks) and longer lease periods would provide more certainty for lenders.

Unanticipated events such as terrorist threats, communicable disease outbreaks (e.g., SARS - Toronto), and pest-borne viral infections (e.g., West Nile virus) can have a detrimental effect on tourism.

The recent appreciation of the Canadian Dollar has negative consequences for the region's tourism sector. The $26 \%$ appreciation in the Canadian dollar since January 2003 has had the dual effect of increasing costs for US visitors to Canada as well as making U.S. destinations more attractive to Canadian visitors.

Water allocation and water availability, as well as the nuisance factor associated with the industry (e.g. noise and dust), were cited as potential barriers to future growth in the manufacturing sector

\subsection{The Manufacturing Sector}

According to one key informant in the manufacturing of construction materials, access to land and other land use issues were challenges for their industry (i.e. competition for land for housing, recreation, etc.). It was also noted that water allocation and water availability, as well as the nuisance factor associated with the industry (e.g. noise and dust), were potential barriers to future growth in the industry.

As noted by an informant in the wood product manufacturing industry, issues related to international trade have the potential to inhibit growth for this industry. For example, the sector is subject to cyclical prices for many commodities, fluctuations in currency exchange rates, U.S. antidumping duties (e.g., softwood lumber) and border security issues, and world growth of export (domestic market does not support high production). Additional weaknesses and threats to the manufacturing sector, the following have been identified:

- Restrictions on the availability of major raw material (i.e. methane from natural gas);

- Competition with other sectors for skilled workers;

- Cost of transporting manufactured goods to major consumer markets;

- Changing and conflicting policies/regulations from different levels of government;

- Environmental regulations/ implementation of the Kyoto Protocol/ legislation on emissions of greenhouse gases;

- Cost of hydrocarbons (natural gas and crude oil) and price volatility; and

- The low cost of natural gas and low cost of labour outside of North America. 


\subsection{The Services Sector}

The services sector is greatly influenced by the nature of the economy and circumstances related to international trade.

The services sector is greatly influenced by the nature of the economy and circumstances related to international trade. For example, poor economic conditions tend to inhibit the ability to expand and maintain a city's infrastructures (i.e. roads, highways, utilities, public transportation, etc.). In addition, fewer funds tend to be made available to hospitals and public education institutions.

In general, the service sector tends to be more insulated from the "boom and bust" cycles that characterize many goods-producing sectors. Health, education, and social service industries do not generally experience wide variation in employment and have traditionally increased at a rate consistent with population growth, however, some sectors (e.g., health) have grown at rates considerably higher than that of the population or general economy.

Other commercial services such as finance and insurance, consulting and other business services are much more dependent on local/regional economic performance. In this context, these support industries are highly dependent on the strength of the goodsproducing sector, although many commercial services are gaining an international reputation for the provision of world-class services.

Investment in this sector plays a critical role in the economy. For example, the provision of opportunities for high-quality education and training are essential in a rapidly growing economy, such as southern Alberta, where there is high demand for skilled labour in a wide variety of occupations.

Key challenges to the long-term growth of the service sector include:

- Ability of government to continue to fund rapidly growing public services (e.g., health);

- Lack of rural access to markets;

- Dependence on goods producing industries for some commercial services;

- Limited competition in the air transportation sector; and

- Border security issues with the US market. 


\section{SECTION 5: IMPACTS OF ECONOMIC GROWTH ON THE NATURAL ENVIRONMENT AND OUALITY OF LIFE}

As industries experience economic growth, a variety of impacts are anticipated for the region(s) in which they are located. The following sections examine some the perceived and anticipated impacts that economic growth might have on aspects of the natural environment like water quantity, air quality, and biodiversity, and to quality of life indicators such as health, infrastructure, and shelter.

The Oldman River's southern tributaries are no longer accepting new licenses and in drier years, the Oldman and Bow rivers cannot fully support the licenses they currently hold.

\subsection{Impacts of Growth on the Natural Environment}

\subsubsection{Water Quantity}

Water quantity was one aspect of the environment in southern Alberta that was of a major concern to industry members, academics, and government key informants interviewed as part of this study. In particular, industries such as oil and gas, agriculture, and livestock production are already beginning to feel impacts due to water licensing and issues regarding resource allocation. Increases in population growth and growth within industries will add to the demand placed on the region's fresh water resources. In 2001, municipal water supplies accounted for $11 \%$ of all the fresh water allocated in Alberta compared to $4.6 \%$ licensed to the oil and natural gas sector and approximately $45 \%$ licensed to the agriculture sector, including irrigation.

Key informants involved in agriculture and irrigation have reported that any expansion in production for their industry will only be the result of technological advances and increased water efficiency and not due to increases in water allocation. For example, recent studies show that further licence allocations in the southern tributaries would be exposed to significant risk of not receiving water due to shortages. The basin currently has 20,000 licenses and registrations, $75 \%$ of which are allocated for irrigation by volume. ${ }^{127}$ The Oldman River's southern tributaries are no longer accepting new licenses and in drier years, the Oldman and Bow rivers cannot fully support the licenses they currently hold. ${ }^{128}$

Recent studies on global warming trends suggest that the southern Alberta region may be experiencing a drying effect. Phenomena such as glacial melting, low run off volumes, low mountain snowpacks, and low spring precipitation ${ }^{129}$ have the potential to decrease river flow volumes and consequently impact urban drinking water supplies as well as a variety of industries in southern Alberta.

\footnotetext{
${ }^{127}$ Corbett, B. and K. Lalonde. "The State of Southern Alberta's Water Resources." < $\underline{h t t p: / / w w w . c o n f r o n t i n g-w a t e r-~}$ scarcity.ca/files/waterresources.pdf> (26 Nov. 2004).

${ }_{128}$ Corbett, B. and K. Lalonde. "The State of Southern Alberta's Water Resources." $<$ http://www.confronting-waterscarcity.ca/files/waterresources.pdf> (26 Nov. 2004).

${ }_{129}$ Alberta Environment. 2004. "Water Supply Outlook for Alberta: Year in Review." $<$ http://www3.gov.ab.ca/env/water/ws/watersupply/oct2004/octTOC.html > (26 Nov. 2004).
} 


\subsubsection{Water Quality}

"Human activities affect the quality of our water. The greatest impacts are usually those associated with the disposal of treated wastewater (from municipalities and industries) into waterways." 130

A number of industries have the potential to negatively impact water quality in Alberta. For example, livestock grazing around riverbanks has adversely affected the province's

Water quality will continue to improve as technology improves and best management practices are incorporated. riparian areas and the native plants and animals associated with those areas. Livestock tend to trample stream banks, reduce or eliminate vegetation and contaminate the water. ${ }^{131}$ The loss of vegetation may also lead to an increase in current velocity, alteration of the path of the current, and an increase in the amount of sediment carried by the current. Improper manure use and management in agriculture may also lead to contamination of surface water. In addition, there are concerns that improper management of saline produced waters from the oil and gas industry may contaminate fresh surface water and groundwater. ${ }^{132}$ However, one environmental scientist interviewed commented that water quality will continue to improve as technology advances and as industry continues to implement and refine best management practices. Because a decrease in water quantity reduces a river's ability to dilute and assimilate contaminants, there may be a need for continuous improvement in best management practices if river flow volumes decline over time.

\subsubsection{Air Quality}

Among key informants in industry, air quality was not considered an issue to the same extent that water quality was, and several of them felt that growth in their particular industry would have little or no impact on air quality. However, a key informant in the construction industry noted that the industry impacts air quality to a moderate extent due to dust generation associated with excavation and extraction.

In the agriculture industry, the expansion of feedlots and intensive livestock operations could also affect air quality. The primary concerns are odour from storing and spreading manure, dust particles and microbial populations, and emissions of ethane and nitrous oxide as greenhouse gases. ${ }^{133}$ However, there is a treatment process that allows for the conversion of raw manure into electrical and thermal energy, organic fertilizer and reusable water. Not only does this reduce reliance on energy from outside sources, but there is also the potential to sell excess energy, also known as biogas, to subsidize their operations. ${ }^{134}$

Growth in the energy sector may affect air quality, such as the proposed construction of a power plant in Brooks. On the other hand, one key informant noted that development in the wind power industry could have a positive impact on air quality, as there would be less reliance on the burning of fossil fuels for energy. In the oil and gas industry, there are regulations specifying the extent that natural gas flaring (burning) and venting

\footnotetext{
${ }^{130}$ Alberta Environment. "Surface Water Quality." 2004. <http://www3.gov.ab.ca/env/water/swq/> (26 Nov. 2004)

${ }^{131}$ Fitch, L., B. Adams and K. O'Shaughnessy. "Caring for the Green Zone: Riparian Areas and Grazing Management." $3^{\text {rd }}$ ed. <http://www.cowsandfish.org/pdfs/greenzone3rd/greenzone3rd.pdf> (26 Nov. 2004).

${ }^{132}$ Griffiths, M and D. Woynillowicz. Oil and Troubled Waters: Reducing the Impact of the Oil and Gas Industry on Alberta's Water Resources. <http://www.pembina.org/pdf/publications/OilandTroubledWaters.pdf> (26 Nov. 2004).

${ }^{133}$ Michalski, S. "Manure Management Systems - Biogas Systems." Advances in Pork Production 14 (2003): 207. $<$ http://www.banffpork.ca/proc/2003pdf/17bMichalski.pdf> (26 Nov. 2004).

${ }^{134}$ Michalski, S. "Manure Management Systems - Biogas Systems." Advances in Pork Production 14 (2003): 207.

$<$ http://www.banffpork.ca/proc/2003pdf/17bMichalski.pdf> (26 Nov. 2004).
} 
Much of the poor air quality in the area could be attributed to pollution in urban areas (i.e. vehicle emissions) particularly in the Calgary basin.

\section{Riparian areas} cover two percent of southern Alberta's landscape but sustain $80 \%$ of its wildlife. (releasing into the atmosphere) that can occur, ${ }^{135}$ however environmental scientists and government informants tend to agree that air quality could be affected by growth in the industry. It should be noted, that the energy industry has reduced gas flaring and venting emissions by $70 \%$ and $38 \%$, respectively. The Clean Air Strategic Alliance (CASA) framework supports the implementation of voluntary measures to develop renewable and alternative energy in Alberta. ${ }^{136}$

Several informants noted that much of the poor air quality in the region could be attributed to pollution in urban areas (i.e. vehicle emissions) particularly in the Calgary basin, which could intensify as the population grows. There was a concern from two key informants that there may not be significant baseline data on air quality to effectively track and analyze air quality in the future.

\subsubsection{Biodiversity}

Urban expansion and growth in industries such as communications, agriculture, construction, and energy have a cumulative effect on the biodiversity in the southern Alberta region. For example, riparian areas cover two percent of southern Alberta's landscape but sustain $80 \%$ of its wildlife. ${ }^{137}$ Research into the importance of preserving and restoring riparian areas has resulted in changes to how some industries operate, especially the livestock and feedlot industries. There is also a concern that diversions of water from rivers for irrigation purposes have adverse affects on the riparian habitats and wetlands.

The installation of communications towers and wind turbines has the potential to impact avian populations in a variety of ways. Site location of wind farms (i.e. an area of heavy migration) seems to be a major factor in the number of collisions that occur and may also have an adverse affect on breeding and wintering birds. ${ }^{138}$

An environmental scientist interviewed noted that economic development tends to lead to an increase in the number of roads created for urban use, recreation, and for industry. These roads tend to disrupt the habitats and animals where they are located. Of particular concern to the scientists is the proposed twinning and expansion of highways through the national parks and through the Crowsnest Pass. According to one environmental scientist, the Crowsnest Pass area is a key migration corridor due to its low elevation and "Highway 3 in particular has the highest death toll in North America due to collisions with animals such as bears, deer, and bighorn sheep."

\subsubsection{Native Habitats and Wetlands}

Habitats and wetlands in southern Alberta may be affected by urban expansion and by the recent trend for urban residents to purchase second homes or summer homes in rural areas or areas that are typically recreational, such as the Canmore region. Further, according to one environmental scientist, the land is negatively impacted through the creation of "artificial roads" by off road vehicles.

\footnotetext{
${ }^{135}$ Alberta Energy and Utilities Board. "Coalbed Methane." 2004. $<$ http://www.eub.gov.ab.ca/BBS/public/EnerFAQs/EnerFAQs10.htm> (26 Nov. 2004).

${ }^{136} \mathrm{http}: / /$ casahome.org/uploads/Renewable_and_Alternative_Energy_Final_Report.pdf

${ }^{137}$ Corbett, B. and K. Lalonde. "The State of Southern Alberta's Water Resources." <http://www.confronting-waterscarcity.ca/files/waterresources.pdf> (26 Nov. 2004).

${ }^{138}$ Kingsley, A. and B. Whittam. "Wind Turbines and Birds: A Guidance Document for Environmental Assessment." 2003. <http://www.canwea.ca/downloads/en/PDFS/BirdStudiesDraft_May_04.pdf> (26 Nov. 2004).
} 
Several key informants commented on how the aesthetics of the region could also be adversely affected by economic growth due to the addition of roads, highways, recreational homes and condominiums, wind farms, and excavation and extraction operations. In turn, the potential for growth in the tourism industry, and for ecotourism in particular, may be adversely affected. ${ }^{139}$

\subsection{Impacts of Growth on Quality of Life}

Impact of economic development on health could be both positive and negative.

\subsubsection{Health}

The health of the residents in the southern Alberta region is typically above average. For example, "Calgary routinely has the highest life expectancy in the Western region" and Calgary has the lowest infant mortality rate compared to other large Canadian cities $^{140}$ and compared to Canada overall. ${ }^{141}$

Opinions of key informants were divided as to how economic development would affect the health of those in the southern Alberta region. Most respondents felt there would be a positive impact in that better economic conditions would allow for more disposable income, provide more money for research, healthier and safer food, and improve infrastructure, and access to health care. However, environmental scientists and social scientists tended to agree that with development comes more noise, traffic congestion, stress, loss of green space, and exposure to more toxins. Remaining informants felt that impacts would be both positive and negative.

\subsubsection{Parkland and Green Space}

The impacts to urban parkland and green space due to development are perceived to be predominantly minimal by most key informants. It was noted by some informants that municipalities tend to have regulations, which allocate a specified amount of land for green space. On the other hand, these urban green spaces tend to be labour and water intensive. One environmental scientist saw development as a threat to native parkland and green space.

\subsubsection{Infrastructure}

The major impact of economic growth on infrastructure will be an increased demand for expansion of the existing system, (i.e. roads, rail, transmission lines, pipelines, utilities, etc.) as well as demands to maintain the existing system. Demand will come from an increase in population as well as a number of industries, such as construction, utilities, transportation, and retail.

Several environmental scientists and key informants from industries such as agriculture and construction, were concerned about the possibility of the expansion or addition of highways. Examples of comments provided are provided below.

"Highway upgrades would have a negative effect on scenic waterways, trout fisheries, and other wildlife."

${ }^{139}$ Marshall, A. "Cloudy Future for Alberta Ecotourism." Wild Lands Advocate 10.3 (2002):1-4 $<$ http://www.albertawilderness.ca/Issues/PLarchive/AR0206WD.pdf> (26 Nov. 2004).

${ }_{140}$ Calgary was compared to other cities in Canada including Ottawa, Edmonton, Toronto, Vancouver, and Winnipeg.

${ }^{141}$ The Calgary Advantage. "Calgary's Regional Quality of Life".

http://www.calgaryadvantages.com/pdf/calgary health and safety.pdf. (12 Jun. 2004). 
Competition for land is due in part to the increasing preference of urban residents to live in suburban communities and commute to work rather than in live the central core.

\section{"Increasing difficulty in providing highways adequate for traffic." \\ "[Development] brings more roads but it may also bring more access to lands where there shouldn't be easy access to."}

\subsubsection{Shelter}

As the population within an urban region increases, the demand for housing stock, and affordable housing in particular, will also increase. As noted by one social scientist, there tends to be insufficient affordable housing. In addition, there is an increasing trend whereby the availability of rental stocks is decreasing due to conversion to condominiums. For example, between 1998 and 1999, "Calgary lost 1,669 rental and row units largely due to conversion to condominiums." ${ }^{142}$ Key informants noted the following:

"There will be a positive impact as there is a larger employed population but affordability is negatively impacted."

"[Development] puts a demand on shelter but also provides more opportunities for people to own, increases construction and adds to the variety of the stock such as seniors' and students' residences."

"If you have more money, you will buy a bigger and better house."

An increase in demand for housing stock also tends to increase competition for land. This competition for land is due in part to the increasing preference of urban residents to live in suburban communities and commute to work rather than in live the central core. ${ }^{143}$ This effect is limited largely to urban areas as most rural areas in southern Alberta are experiencing decreases in population due to migration of its residents to urban areas.

\subsubsection{General Quality of Life}

The majority of the environmental and social scientists interviewed reported that, in their opinion, economic development would have an overall negative affect on quality of life due to traffic congestion, strains on infrastructure, urban sprawl, and loss of aesthetics. In addition, one social scientist noted that since economic development favours extractive industries in the region, the impact would tend to be negative.

On the other hand, the majority of key informants from government reported that economic development would have an overall positive effect on quality of life. For example, it was said that change and growth was necessary to attract people into the region, it would bring more prosperity to the area and improve infrastructure. Economic development provides the financial resources to support necessary social infrastructure including schools, hospitals, and social housing.

Responses from industry participants were both positive and negative while responses from economists were primarily positive. For example, it was felt that more money in the economy meant more provision of services to the residents and increased personal comfort levels.

\footnotetext{
${ }^{142}$ The Calgary Advantage. "Calgary's Regional Quality of Life, Affordability".

http://www.calgaryadvantages.com/pdf/calgary affordability.pdf (12 Jun. 2004).

${ }^{143}$ Hofmann, N. "Urban Consumption of Agricultural Land." Rural and Small Town Canada Analysis Bulletin. 3.2 (2001) <http://www.statcan.ca/english/freepub/21-006-XIE/21-006-XIE01002.pdf> (26 Nov. 2004)
} 


\subsection{Managemēnt of Competing Interests}

In regards to the interviews undertaken with key informants, almost half of the responses provided indicated that communication was the key to managing competing interests. Examples of comments provided by key informants have been provided below.

"Processes must be collaborative, integrated, multi-objective and inclusive for all communities of interest."

"Get public support through collaboration and assurance of mutual gains."

"Consult with those affected directly and indirectly as early as possible in the process."

Several additional comments were made regarding planning and focusing on long term goals and outcomes, placing value on the environment, creating a dynamic plan that can be revised as needed, and taking the watershed into account when developing a plan.

On the other hand, several economists interviewed felt that future land use issues should be resolved by the landowners and through market demands.

\subsection{Managing Impacts of Human Activity on the Environment}

We've learned through technology how to better manage waste, improve our mainstream rivers, and improve air quality.

While undertaking interviews with key informants, environmental scientists were asked what research has taught us in terms of reducing or better managing the impact of human activity on the natural environment. Comments from the scientists varied and included the following:

"There is a better understanding of how and where to operate so that so that longterm impacts on the landscape are reduced."

"We've learned through technology how to better manage waste, improve our mainstream rivers, and improve air quality."

"We are more aware of decreasing biodiversity, the impacts of global warming and the effects of glacial ice melting."

"There is reduced pesticide use in some areas, however, they may still be carried by air into other regions."

"We can project demographic growth but not enough planning is being done to prepare for it."

One scientist further noted that, although we have learned how to better manage and improve the quality of aspects of the environment, the challenge is in applying what we have learned. 
APPENDIX A: RESEARCH METHODOLOGY AND RESEARCH CONSIDERATIONS 
Research Methodology

As part of this study, the Consultant undertook two main data collection activities, a comprehensive literature and statistical review, and key informant interviews.

Documents included in the literature review were obtained from three main sources: 1) the client, 2) Internet searches, and 3) those recommended by key informants during the interview process. A bibliographical listing of the documents reviewed for this study can be found in Appendix B.

Between November $5^{\text {th }}$ and November $30^{\text {th }}, 2004$, the Consultant completed 31 interviews with key informants. Prior to the interview, key informants were sent a copy of the Project Steering Committee-approved interview guide in order to ensure their participation was appropriate and to better prepare them for the interview. Due to the diverse locations of the respondents, key informant interviews were conducted by telephone. On average, interview times ranged between 30 minutes and one hour. Further details regarding the number of interviews completed and the topics covered can be found in the table below.

Key Informant Data Collection Activities

\begin{tabular}{|c|c|c|}
\hline Data Source & $\begin{array}{l}\text { Number of } \\
\text { Interviews }\end{array}$ & Issues and Topics Addressed \\
\hline $\begin{array}{l}\text { Federal/Provincial/ } \\
\text { Municipal Government } \\
\text { Staff }\end{array}$ & 11 & $\begin{array}{l}\text { - Extent of current economic and } \\
\text { environmental development } \\
\text { - Trends and factors affecting trends } \\
\text { - Strengths and opportunities within economic } \\
\text { sectors } \\
\text { - Weakness and threats within the sector } \\
\text { - Factors that may lead to an increase or } \\
\text { - decline in their sector's activity } \\
\text { - Up and coming projects } \\
\text { - Key environmental issues }\end{array}$ \\
\hline $\begin{array}{l}\text { Sector and Industry } \\
\text { Association Stakeholders }\end{array}$ & 10 & $\begin{array}{l}\text { - Geographic supply and demand patterns } \\
\text { - Strengths and opportunities within the sector } \\
\text { - Weakness and threats within the sector } \\
\text { - Factors that may lead to an increase or } \\
\text { decline in their sector's activity } \\
\text { - Impacts on quality of life indicators } \\
\text { - Climate variability and other natural threats } \\
\text { - Up and coming projects } \\
\text { - Key environmental issues }\end{array}$ \\
\hline
\end{tabular}




\begin{tabular}{|c|c|c|}
\hline Data Source & $\begin{array}{l}\text { Number of } \\
\text { Interviews }\end{array}$ & Issues and Topics Addressed \\
\hline Economists & 4 & $\begin{array}{l}\text { Economic trends and activities defining the } \\
\text { region } \\
\text { - Factors contributing to trends (trade, } \\
\text { technology, legislation, etc.) } \\
\text { - Effect of environmental policies on economic } \\
\text { performance } \\
\text { - Geographic supply and demand patterns } \\
\text { - Impacts on quality of life indicators } \\
\text { - Demand forecasts } \\
\text { - Up and coming projects } \\
\text { - Key environmental issues }\end{array}$ \\
\hline Environmental Scientists & 4 & $\begin{array}{l}\text { Environmental impacts resulting from } \\
\text { economic development in key sectors (air } \\
\text { and water quality, etc.) } \\
\text { - Effect of environmental policies on economic } \\
\text { performance } \\
\text { - Impacts on quality of life indicators } \\
\text { - Climate variability and other natural threats } \\
\text { (e.g. drought) }\end{array}$ \\
\hline Social Scientists & 2 & - Impacts on quality of life indicators \\
\hline
\end{tabular}

Responses from the informant interviews were categorized by key themes to supplement findings from the literature review.

\section{Research Considerations}

\section{Limitations of Key Informants}

It should be noted that interviews with key informants were undertaken with a crosssection of academics and professionals related to the industries of concern to the study. The information generated is anecdotal in nature and reflects the professional views and opinions of experts in the field. In addition, the majority of the views expressed were made by a limited number of persons in each industry and field, and therefore may not necessarily reflect the views of all those involved. However, responses from the interviews were corroborated with information gathered during the literature whenever possible. 


$$
\mid-
$$




\section{BIBLIOGRAPHY}

"2003 Alberta Agronomy Update Conference: January 13-14.” 2003.

$<$ http://www.reducedtillage.ca/2003proceedings.pdf $>$ (26 Nov. 2004).

AERIC, Inc. Insights on Western Canada: A Socio-Economic Report. Ottawa: The Conference Board of Canada, 2003.

AERIC, Inc. "Performance and Potential 2004-05: How can Canada Prosper in Tomorrow's World?" The Canada Project 2004.

http://www.embaspain.ca/boletin/10112004/Conference\%20Board\%20200405.pdf (26 Nov. 2004).

Alberta Advantage. Alberta Advantage Statistics and Publications. Alberta: Government of Alberta, 2004.

Alberta Agriculture, Food and Rural Development. Alberta Agri-Food Industry Growth Strategy: $\$ 20 / \$ 10$ by 2010 . Alberta: Government of Alberta, 2003.

Alberta Construction Association. On the Rollercoaster.

$<$ http:www.abconst.org/forecasts/ACAForecast_2005.pdf> (15 Dec. 2004).

Alberta Economic Development. "Alberta Quick Facts: September 2004." $<$ http://www.alberta-canada.com/statpub/pdf/quickfact_sept04.pdf $>$ (26 Nov. 2004).

Alberta Economic Development. "Frequently Requested Alberta Tourism Statistics." Tourism Statistics Report 1996-2003. <http://www.albertacanada.com/statpub/pdf/frequentTourismQuestions.pdf> (26 Nov. 2004).

Alberta Economic Development. "Alberta Economic Development Monthly Economic Review November 2004." <http://www.albertacanada.com/statpub/pdf/MER_Nov2004.pdf> (26 Nov. 2004).

Alberta Economic Development. "Facts on Alberta." <http://www.albertacanada.com/statpub/pdf/FactOnAB2003.pdf> (26 Nov. 2004).

Alberta Economic Development. "Highlights of the Alberta Economy, Winter 2004." $<$ http://www.alberta-canada.com/statpub/pdf/news_HighlightsWinter2004. pdf> (26 Nov. 2004).

Alberta Economic Development. "Alberta's International Merchandise Exports: January to June 2004." 2004. <http://www.albertacanada.com/statpub/pdf/news_TradeReview2ndQ2004.pdf> (26 Nov. 2004).

Alberta Energy and Utilities Board. "Coalbed Methane." 2004. $<$ http://www.eub.gov.ab.ca/BBS/public/EnerFAQs/EnerFAQs10.htm> $(26$ Nov. 2004). 
Alberta Environment. "Surface Water Quality." 2004.

$<$ http://www3.gov.ab.ca/env/water/swq/> (26 Nov. 2004).

Alberta Environment. "Water for Life: Alberta's Strategy for Sustainability." 2003. <http://www.waterforlife.gov.ab.ca/docs/strategyNov03.pdf> (26 Nov. 2004).

Alberta Environment. 2004. "Water Supply Outlook for Alberta: Year in Review." $<$ http://www3.gov.ab.ca/env/water/ws/watersupply/oct2004/octTOC.html> (26 Nov. 2004).

Alberta Environment. "Highlights of Integrated Resource Management in Alberta Year 2000." 2000. $<$ http://www3.gov.ab.ca/env/irm/Highlights_IRM_2000.pdf> (26 Nov. 2004).

Alberta Finance. "Budget 2004: Government of Alberta Strategic Business Plan." 2004.

$<$ http://www.finance.gov.ab.ca/publications/budget/budget2004/govbp.html> (26 Nov. 2004).

Alberta Finance. "Budget 2004: Economic Outlook 2004-07." 2004.

$<$ http://www.finance.gov.ab.ca/publications/budget/budget2004/eco.html> (26 Nov. 2004).

Alberta Finance. "Budget 2004: Fiscal plan 2004-07." 2004. $<$ http://www.finance.gov.ab.ca/publications/budget/budget2004/fiscal.html > (26 Nov. 2004).

Alberta Finance. "Budget 2004: Capital plan 2004-07." 2004. $<$ http://www.finance.gov.ab.ca/publications/budget/budget2004/capplan.html $>$ (26 Nov. 2004).

Alberta Finance. "Budget 2004: Alberta Advantage." 2004. $<$ http://www.finance.gov.ab.ca/publications/budget/budget2004/abadv.html > (26 Nov: 2004).

Alberta Finance. "Budget 2004: Alberta Tax Advantage." 2004. $<$ http://www.finance.gov.ab.ca/publications/budget/budget2004/tax.html> (26 Nov. 2004).

Alberta First. "Community Profiles." 2004. <http://www.albertafirst.com/profiles/> (26 Nov. 2004).

Alberta Human Resources and Employment. " 2002 Annual Alberta Labour Market Review." 2004. <http://www3.gov.ab.ca/hre/lmi/pdf/2002lmreview.pdf> (26 Nov. 2004).

Alberta Human Resources and Employment. (2004a) "2003 Annual Alberta Labour Market Review." 2003. $<$ http://www3.gov.ab.ca/hre/lmi/pdf/2003lmreview.pdf> (26 Nov. 2004). 
Alberta Human Resources and Employment (2004b)

"Alberta Profile: Aboriginal People in the Labour Force"

$<$ http://www3.gov.ab.ca/hre/lmi/pdf/aboriginal_profile1.pdf> (07 Sept. 2004).

Alberta Human Resources and Employment (2004d)

"Labour Force Statistics: June, 2004"

$<$ http://www3.gov.ab.ca/hre/lmi/pdf/labour_productivity.pdf>(07 Sept. 2004)

Alberta Human Resources and Employment (2004e)

"Labour Force Statistics: June 2004, Highlights"

$<$ http://www.gov.ab.ca/acn/images/2004/704/16786(8).pdf> (07 Sept. 2004)

Alberta Human Resources and Employment. "Alberta Regional Occupation Outlook: 2004-2009, Banff-Jasper-Rocky Mountain House Economic Region Summary Report". 2004, October.

<www3.gov.ab.ca/hre/lmi/pdf/occ/_forecast_Banff.pdf> (10 Jan. 2004).

AlbertaFirst.com (2004a)

"Calgary Region Marketplace"

$<$ http://www.albertafirst.com/profiles/marketplace/> (07 Sept. 2004)

AlbertaFirst.com (2004b)

"Southeast Alberta Marketplace"

$<$ http://www.albertafirst.com/profiles/marketplace/> (07 Sept. 2004)

AlbertaFirst.com (2004c)

"Southwest Alberta Marketplace"

$<$ http://www.albertafirst.com/profiles/marketplace/> (07 Sept. 2004)

Alberta Prairie Conservation Forum. Alberta Prairie Conservation Action Plan 19962000. 1996. <http://www.albertapcf.ab.ca/apcap.htm> (26 Nov 2004).

Alberta Sustainable Resource Development. "Bighorn Backcountry Access Management Plan." 2002.

$<$ http://www3.gov.ab.ca/srd/regions/southwest/ghost/pdf/access_management plan.pdf> (26 Nov. 2004).

Alberta Wilderness Association. "Opposition Grows to Proposed Magnetite Mine in Prime Wildlife Habitat."

$<$ http://albertawilderness.ca/awrc/enews/en2004/1s040115.htm> (26 Nov. 2004).

Antwi-Buadum, S. The Economic Value of Natural Habitats: Review of Empirical Literature. Winnipeg: Ducks Unlimited Canada, 2003.

The Applied History Research Group. "Multimedia History Tutorials." 2001. $<$ http://www.ucalgary.ca/applied_history/tutor/calgary/> (26 Nov. 2004). 
Azmier, J.J. and S. Dobson. "The Burgeoning Fringe: Western Canada's Rural Metro-Adjacent Areas." Building the New West Report 23 (2003). $<$ http://www.cwf.ca/abcalcwf/doc.nsf/publications?ReadForm\&id=65F23596 0822C1E187256DFA007DBB05> (26 Nov. 2004).

Bachu, S. and S. Stewart. "Geological Sequestration of Anthropogenic Carbon Dioxide in the Western Canadian Sedimentary Basin: Suitability Analysis." $<$ http://www.science.uwaterloo.ca/course_notes/earth/earth437/CarbonSeques tration/BachuStewartJCPTCO2.pdf> (26 Nov. 2004).

Bradley, P.G. and G.C. Watkins. "Commentary: Canada and the U.S.: A Seamless Energy Border?" 2003. <http://www.cdhowe.org/pdf/Commentary_178.pdf> (26 Nov. 2004).

Brady, B. and F. Novin. "Bank of Canada Review: Factors Affecting Regional Economic Performance in Canada." 2001. <http://www.bank-banquecanada.ca/publications/review/bradye.pdf $>$ (26 Nov. 2004).

Blouin, F. "The Southern Headquarters at Risk Project: A Multi-species Conservation Strategy for the Headwaters of the Oldman River." Vol. 1. 2004. $<$ http://www3.gov.ab.ca/srd/fw/speciesatrisk/pdf/SAR_89.pdf> (26 Nov. 2004).

Brown \& Associates Planning Group, Prepared in Conjunction with D.A. Watt Consulting Group Ltd. and Clayton Research Associates Ltd. City of Airdrie Growth Study 2000. Airdrie: City of Airdrie, 2001.

Burleton, D., M. Curtis-Irving, and I. Philipoff. "The Calgary-Edmonton Corridor: Take Action Now to Ensure Tiger's Roar Doesn't Fade." TD Economics Special Report 2003.

Canada Alberta Beef Industry Development Fund. "Reducing Feedlot Dust and BioAerosols." < http://www.albertabeef.org/cabidf/03reports/59abiolaF.html> (26 Nov. 2004).

The Centre for Spatial Economics and Alberta Human Resources and Employment. Alberta Regional Occupation Outlook. Edmonton: Alberta Human Resources and Employment, 2002.

The Centre for Spatial Economics. Economic Outlook Summary. 2002. $<$ http://www/c4se.com/Alberta\%20Forecast.pdf $>$ (15 Dec. 2004).

Chambers, E.J. and M. Deans. "The Rural Renaissance in Alberta: Some Empirical Evidence." Information Bulletin \#50. 1998. $<$ http://www.bus.ualberta.ca/CIBS\%2DWCER/WCER/pdf/50.pdf> (26 Nov. 2004).

The Conference Board of Canada. "Provincial Outlook Autumn 2004: Economic Forecast." 2004.

$<$ http://www.conferenceboard.ca/documents.asp?rnext=1015> (26 Nov. 2004). 
Corbett, B. and K. Lalonde. "The State of Southern Alberta's Water Resources." $<\mathrm{http}: / /$ www.confronting-water-scarcity.ca/files/waterresources.pdf $>$ (26 Nov. 2004).

Corporate Studies and Economics. "Calgary and Region: Socio-Economic Outlook 2003-2008." 2003.

$<$ http://www.calgary.ca/cweb/communities/community.asp?UserID=2\&comm unityid $=200 \&$ intCurrentPageIndex $=6>(26$ Nov. 2004).

Corporate Studies and Economics. "Calgary's Shifting Socio-Economic Landscape: A Long-Term Forecast of the Economy and Society 2003-2033."

$<$ http://www.calgary.ca/cweb/communities/community.asp?UserD=2\&comm unityid $=200 \&$ int CurrentPageIndex $=6>(26$ Nov. 2004) .

Dianne Lougheed Keefe Consulting Inc. Economic Development Strategic Assessment. Medicine Hat: The City of Medicine Hat, 2002.

Dianne Lougheed Keefe Consulting Inc. Palliser Economic Partnership: Economic Development Strategy. Medicine Hat: Dianne Lougheed Keefe Consulting Inc., 2003.

Duke, D, M. Quinn, Butts, B, Lee-Ndugga, T. and K. Wilkie. Spatial Analysis of Rural Residential Expansion in Southwestern Alberta. Calgary: Miistakis Institute for the Rockies, 2003.

Economic and Demographic Analysis, Data Development and Evaluation for Alberta Human Resources and Employment. "Annual Alberta Regional Labour Market Review." 2003.

$<$ http://www3.gov.ab.ca/hre/lmi/pdf/2003_aarlmr.pdf $>$ (26 Nov. 2004).

Economic and Demographic Analysis, Data Development and Evaluation for Alberta Human Resources and Employment. "Alberta Regional Population Outlook 2004-2009.” 2004. <http://www3.gov.ab.ca/hre/lmi/pdf/200409 _outlook.pdf> (26 Nov. 2004).

Economic Development Department. "Lethbridge Community Profile 2002-2003." $<$ http://www.city.lethbridge.ab.ca/profile> (26 Nov. 2004).

Fitch, L., B. Adams and K. O'Shaughnessy. "Caring for the Green Zone: Riparian Areas and Grazing Management." $3^{\text {rd }}$ ed. $<$ http://www.cowsandfish.org/pdfs/greenzone3rd/greenzone3rd.pdf $>$ (26 Nov. 2004).

Gard, Robert E. Southern Alberta: History and Tale. 2 Vols. Edmonton: University of Alberta Libraries. Alberta Folklore and Local History Collections, nd.

George, M.V., S. Loh, Verma, R.B.P., Shin, Y.E. "Population Projections for Canada, Provinces and Territories 2000-2026." 2001. $<$ http://xnet.rrc.mb.ca/library/stats2/stat09/0012691-520-XIB.pdf> (26 Nov. 2004). 
Global Training, Inc. Southern Alberta Landscapes: Meeting the Challenges Ahead: Social/Economic Aspects. Edmonton: Unpublished Report Prepared for Alberta Environment, 2004.

Griffiths, M and D. Woynillowicz. Oil and Troubled Waters: Reducing the Impact of the Oil and Gas Industry on Alberta's Water Resources.

$<$ http://www.pembina.org/pdf/publications/OilandTroubledWaters.pdf $>(26$ Nov. 2004).

Hofmann, N. "Urban Consumption of Agricultural Land." Rural and Small Town Canada Analysis Bulletin. 3.2 (2001) $<$ http://www.statcan.ca/english/freepub/21-006-XIE/21-006-XIE01002.pdf $>$ (26 Nov. 2004)

Hydroconsult EN3 Services, Ltd. and Canadian Resource Economics, Ltd. South Saskatchewan River Basin Non-Irrigation Water Use Forecasts. Calgary: Alberta Environment, 2002.

Kingsley, A. and B. Whittam. "Wind Turbines and Birds: A Guidance Document for Environmental Assessment." 2003. $<$ http://www.canwea.ca/downloads/en/PDFS/BirdStudiesDraft_May_04.pdf $>$ (26 Nov. 2004).

Lethbridge City Council. A Shared Direction for the Future. Lethbridge: The City of Lethbridge, 2002.

Liu, X. and R. Mirus. "Alberta's and Western Canada's Exports: 15 Years of Free Trade Agreements." Information Bulletin \#80 2004.

$<\mathrm{http}: / /$ www.bus.ualberta.ca/CIBS-WCER/> (26 Nov. 2004)

MacKendrick, N., C. Fluet, D. Davidson, N. Krogman, M. Ross. "Integrated Resource Management in Alberta's Boreal Forest: Opportunities and Constraints." 2001. <http://sfm1.biology.ualberta.ca/english/pubs/PDF/PR_2001-22.pdf> (26 Nov. 2004).

Marshall, A. "Cloudy Future for Alberta Ecotourism." Wild Lands Advocate 10.3 (2002): $1-4$ $<$ http://www.albertawilderness.ca/Issues/PL/archive/AR0206WD.pdf $>$ (26 Nov. 2004).

Meristem Information Resources Ltd. "New Research to Protect Canada's Rangeland." Land \& Science: Beef Science 2002. $<$ http://www.meristem.com/beef/bfs02_11.html >

Michalski, S. "Manure Management Systems - Biogas Systems." Advances in Pork Production 14 (2003): 207. $<$ http://www.banffpork.ca/proc/2003pdf/17bMichalski.pdf> (26 Nov. 2004). 
Miistakis Institute for the Rockies. Sustainable Development: A Review of Current Literature on Sustainable Development for the Southern Alberta Landscapes: Meeting the Challenges Ahead. Calgary: Unpublished Report Prepared for Alberta Environment, Integrated Resource Management, 2004.

Nichols Applied Management. "Central Alberta Economic Partnership Pilot Project: Regional Economic Profile Model." Cross-Ministry Task Team \#5 $<$ http://www.centralalberta.ab.ca/content/assets/regionalprofilemodelMay200 3.pdf> (26 Nov. 2004).

Page, Bob. "Integrating Climate Change into Impact Assessment: Challenges for Integrity and Credibility."

<http://www.iaia.org/Non_Members/Conference/LAIA04/04\%20CD$\mathrm{ROM} /$ Keynote-

Speeches/OP\%20Bob\%20Page\%20Integrating\%20Climate $\% 20$ Change $\% 20$ in to $\% 20 I A . p d f>$ (26 Nov. 2004).

Parks Canada Agency. Trans Canada Highway Phase IIIB Upgrade Environmental Screening: Background Information. 2004.

$<$ http://www.praxis.ca/banfftwinning/pdfs/EA_Backgrounder.pdf $>$ (26 Nov. 2004).

Policy \& Economic Analysis Division. Winter 2004: Highlights of the Alberta Economy. Alberta: Alberta Economic Development, 2004.

PWC Consulting. “Alberta Forest Industry Supply and Service Sector Study: Understanding Alberta's Business and Industry Sector Needs for the $21 \mathrm{st}$ Century." 2000. <http://www.albertacanada.com/statpub/pdf/forest_study.pdf> (26 Nov. 2004).

PWC Consulting. "Alberta Aboriginal Tourism Product Opportunity Analysis." 2002. <http://www.alberta-canada.com/statpub/pdf/aborig_pres.pdf $>$ (26 Nov. 2004).

Sciences \& Standards Branch. “Alberta's Ambient Air Quality Objectives: Facts at your Fingertips." <www.gov.ab.ca/env> (26 Nov. 2004).

Serecon Management Consulting Inc. "Socio-Economic Impact of Hog Operations in Alberta." < http://sfm-1.biology.ualberta.ca/english/pubs/PDF/PR_200122.pdf> (26 Nov. 2004).

Sinclair, L . "The Assessment of Selected Decision Tools for Evaluation of Strategies for Climate Change Adaptation." 2001.

$<$ http://www3.gov.ab.ca/env/air/pubs/AssessmentofSelectedDecisionToolsfor EvalofStrategiesforCCAdaptation.pdf $>$ (26 Nov. 2004).

Smart, J. "Borrowed Men on Borrowed Time: Globalization, Labour Migration and Local Economies in Alberta." 1997. $<$ http://www.lib.unb.ca/Texts/CJRS/Spring97/20.1_2/smart.pdf> (26 Nov. 2004). 
Southern Alberta Environmental Group. "Questions and Concerns Regarding the Milk River Basin: Preliminary Feasibility Study." 2003.

$<$ http://www.ijc.org/rel/pdf/46_stmary-milk_letter.pdf> (26 Nov. 2004).

Suncor Energy, Inc. "Suncor, EHN and Enbridge Generate Electricity from Southern Alberta Wind Power Project." 2004.

$<$ http://www.suncor.com/links_popup.aspx?ID=2395> (26 Nov. 2004).

"Sustainable Calgary." <http://www.sustainablecalgary.ca/pages/about.htm> (26 Nov. 2004).

Sustainable Resource Development. "Shifting Gears."

$<$ http://www3.gov.ab.ca/srd/regions/southwest/shifting-gears/index.html> (26 Nov. 2004).

Urban Futures Inc. "Population Projections for the City of Lethbridge: 2001 to 2031." $<$ www.urbanfutures.com> (26 Nov. 2004).

Wilkie, K. and R. Roach. Green Among the Concrete: The Benefits of Urban Natural Capital. A Natural Capital Project Discussion Paper. Calgary: Canada West Foundation, 2004. 
APPENDIX C: BACKGROUND AND HISTORICAL ISSUES 


\section{BACKGROUND AND HISTORICAL ISSUES}

This section provides an overview of historical issues specific to southern Alberta that have had an impact on the current economic and environmental situation in the region.

\section{Early History}

When Canada was formed in 1867, what is now southern Alberta was still an uncontrolled frontier. In preparation for incoming homesteaders, the government surveyed the land into townships beginning in 1871. The following year, it enacted the Dominion Lands Act, which enabled legal settlement and entitlement of the land by mostly European settlers.

The North West Mounted Police, the precursor to the modern Royal Canadian Mounted Police (RCMP), arrived in what would become Fort Macleod in October 1874. A detachment of the Mounted Police was established at Fort Calgary and the territorial government was created in 1875 .

Initially, Calgary's economy was predominantly dependent on cattle ranching and agriculture. However, Calgary quickly became the economic centre for the developing region, was incorporated as a town in November 1884. As small towns developed along the rail lines; their residents looked to Calgary for supplies. As a consequence, the city became Alberta's first wholesale centre. Less than 10 years later, in September 1893 with a population of approximately 2,500, Calgary was incorporated as a city. Calgary was the first community to gain city status in the Northwest Territories.

From 1896 to 1914, the rural population of southern Alberta expanded dramatically. Irrigation was vital to successful farming throughout the region. The Province of Alberta was created in 1905 and by 1910 settlers had cultivated 3.3 million acres (1.34 million ha) of land in the province. The boom, which saw the population of Calgary increase from nearly 12,000 in 1906 to approximately 44,000 in 1911, was underway. In 1907, Calgary was promoted as the "commercial metropolis of Western Canada".

Following World War I, the economy of southern Alberta collapsed. Drought, inflation and the end of the immigration boom sent the economy into a depression. By $1923,80 \%$ of the province's farmers experienced bankruptcy. It is estimated that south-eastern Alberta lost 55\% of its population by 1926 .

The Great Depression of the 1930's served to further devastate prairie agriculture. Wheat prices plunged, and net farm incomes fell from \$102 million in 1928 to \$5 million in 1933. Prolonged drought and poor cultivation methods promoted soil erosion that resulted in dust storms. As well, southern Alberta experienced a serious grasshopper infestation. Entire rural communities became ghost towns during this time, particularly within Palliser's Triangle ${ }^{144}$.

${ }^{144}$ University of Calgary. http://www.ucalgary.ca/applied_history/tutor/calgary/ (17 Nov. 2004) 
Coal mining played a large role in the early development of the province, supplying coal domestically and to the CPR. Alberta's first coal miner, Nicholas Sheran, began digging coal from the banks of the Belly River opposite Lethbridge in $1882 .{ }^{145}$ Coal mining on a commercial scale commenced in the southern Alberta communities of Medicine Hat (1883), Lethbridge (1886), Canmore (1888), Blairmore (1900), Three Hills (1906) and Drumheller (1911). ${ }^{146}$

However, it was the discovery of oil and gas in southern Alberta that would eventually pave the way to a prosperous future. The CPR discovered gas in a water well at Langevin Siding, 35 miles west of Medicine Hat, in 1883 and drilled a second well in $1884 .{ }^{147}$ In 1909 , southern Alberta's first major natural gas discovery was made from the Old Glory well at Bow Island. In 1901-02, Western Canada's first oil well was established in Waterton. ${ }^{148}$ Oil was discovered at Turner Valley in 1914, and Calgary began building its industry around oil and gas. ${ }^{149}$

By 1921, a pipeline carrying gas from the Turner Valley field began supplying the City of Calgary. From 1914 to 1947, the Turner Valley oil field produced 97 percent of Alberta's oil and gas. In 1930, Alberta's mineral rights were transferred from the Dominion to the province. Alberta then established the Department of Lands and Mines (now the Alberta Department of Energy) to oversee its resources.

Impact of World War II

The onset of World War II marked the end of the unemployment crisis in southern Alberta. Armed forces bases and the Suffield Chemical Warfare Research Station brought in military personnel from other provinces and countries, which led to the expansion of the construction and service industries in many local Alberta communities. The establishment of prisoner of war camps, particularly in Lethbridge and Medicine Hat, also had a major impact on local economies.

The expanded need for fossil fuels for the war effort generated new activity in the region's coalfields, and brought renewed interest in Alberta's heavy oil reservoirs. The energy demands of the war years served as the catalyst for Alberta's economic dependence on oil and gas reserves.

World War II also contributed to major changes in southern Alberta's farming industry. It ended the agricultural depression, but also altered the economic structure of the industry and the region's demographic profile. Labour shortages due to the war effort, and improvements in the quality of farm machinery accelerated the rate of farm mechanisation. The shift to large farm operations required fewer farm labourers, and

\footnotetext{
${ }^{145}$ University of Alberta Libraries, Alberta Folklore and History Collection. http://folklore.library.ualberta.ca/BigImages/09070218.jpg (16 Nov. 2004)

${ }^{146}$ University of Alberta Libraries, Alberta Folklore and History Collection. http://folklore.library.ualberta.ca/BigImages/0907206.jpg (16 Nov. 2004)

${ }^{147}$ Petroleum History Society. http://www.petroleumhistory.ca/history/firstgas.html (16 Nov. 2004)

${ }_{148}$ WatertonPark.com. http://www.watertonpark.com/reference/chronology.htm (16 Nov. 2004)

${ }^{149} \mathrm{http}: / / \mathrm{www}$. calgary-convention.com/public html/experience history.asp
} 
coupled with southern Alberta's booming towns and cities, rapid urbanization ensued. The province's overall population changed little during WWII, however, by 1951 over half the province's people lived in urban areas. ${ }^{150}$

\section{The Oil and Gas Boom}

Following the conclusion of the war, a substantial oil find was made in Leduc on February 13, 1947, which transformed Alberta into an oil-rich province.

Fuelled largely by oil and gas revenues following the Second World War, Calgary experienced phenomenal urban growth. In the 1960's, agriculture accounted for just twenty percent of Calgary's industry, while Canadian oil and gas expertise had been centralized in the city. By 1983 the Canadian Oil Registry listed Calgary as the base of 638 head offices, or 76 percent of Canada's oil and gas producers, explorers, and developers, as well as 1,387 oil related companies. Calgary's population grew from nearly 100,000 people in 1946 to over 400,000 in 1971 , and from 750,000 in the early 1990 's to more than 930,000 by 2004 .

Recent Impacts to the Southern Alberta Region

Alberta continued to be susceptible to boom and bust cycles due to its reliance on oil and gas. In 1981, the world price of oil was $\$ 44$ a barrel; by 1986, the price collapsed to $\$ 10$ a barrel. In addition, agricultural prices fell dramatically due to world grain surpluses, and a series of dry years in the early 1980's resulted in bankruptcies and rising debt. This economic recession resulted in a net-migration out of the province. ${ }^{151}$

Although the price of oil remained relatively low in real dollars throughout much of the 1990's, the rise of the technology sector helped to further diversify the Calgary region, and fostered much of the region's economic growth during the decade. Since 1995 , Calgary's advanced technology sector has been growing by $15 \%$ to $20 \%$ each year. The industry employs over 70,000 people, and is valued at $\$ 16$ billion annually. $^{152}$

Recently, the southern Alberta region has witnessed divergent patterns for two key economic sectors. While the oil and gas sector has benefited from high energy prices, which has in turn stimulated record exploration and capital investment, the region's agricultural sector has been impacted by the closure of the US market to Alberta producers due to concerns about Bovine Spongiform Encephalopathy (BSE). In contrast to the oil and gas sector, agricultural producers have had to contend with fluctuating prices for both livestock and grain crops. Depressed cattle prices combined with rising prices for fuel/transportation has negatively affected many agricultural operations. It is expected, however, that re-opening of the US market to Canadian cattle, will return the region's agricultural sector to higher levels of profitability.

\footnotetext{
${ }^{150}$ University of Calgary. http://www.ucalgary.ca/applied history/tutor/calgary/ (17 Nov. 2004)

${ }^{151}$ University of Calgary. http://www.ucalgary.ca/applied history/tutor/calgary/ (17 Nov. 2004)

${ }^{152}$ Calgary Technologies Inc. http://www.calgarytechnologies.com/bins/content page.asp?cid=328 (17 Nov. 2004)
} 


$$
\mid-
$$


Regional Growth by Forecast Period

\begin{tabular}{|c|c|c|c|c|}
\hline \multirow{2}{*}{ Region } & \multicolumn{4}{|c|}{ Forecast Period } \\
\cline { 2 - 5 } & $\mathbf{2 0 0 4}$ & $\mathbf{2 0 0 5 - 2 0 1 4}$ & $\mathbf{2 0 1 5 - 2 0 2 4}$ & $\mathbf{2 0 0 5 - 2 0 2 4}$ \\
\hline Lethbridge-Medicine Hat & & & $1.7 \%$ & $2.1 \%$ \\
\hline Real GDP & $9208.5^{*}$ & $2.5 \%$ & $1.3 \%$ & $1.4 \%$ \\
\hline Employment & 129,400 & $1.6 \%$ & $1.2 \%$ & $1.3 \%$ \\
\hline Population & 261,100 & $1.5 \%$ & & \\
\hline Camrose-Drumheller & & & $1.5 \%$ & $1.8 \%$ \\
\hline Real GDP & $6599.1 *$ & $2.2 \%$ & $1.2 \%$ & $1.6 \%$ \\
\hline Employment & 97,400 & $1.9 \%$ & $1.4 \%$ & $1.3 \%$ \\
\hline Population & 190,400 & $1.3 \%$ & & \\
\hline \hline Calgary & & & $2.3 \%$ & $2.6 \%$ \\
\hline Real GDP & $50,487.4 *$ & $3.0 \%$ & $1.5 \%$ & $1.7 \%$ \\
\hline Employment & 659,500 & $1.9 \%$ & $1.4 \%$ & $1.6 \%$ \\
\hline Population & $1,129,700$ & $1.8 \%$ & & \\
\hline Red Deer & & & $1.7 \%$ & $2.0 \%$ \\
\hline Real GDP & $6396.3 *$ & $2.3 \%$ & $1.0 \%$ & $1.3 \%$ \\
\hline Employment & 87,300 & $1.5 \%$ & $1.3 \%$ & $1.0 \%$ \\
\hline Population & 166,100 & $1.0 \%$ & $0.9 \%$ & \\
\hline Weighted Average & & & & $2.4 \%$ \\
\hline Real GDP & -- & $2.7 \%$ & $2.1 \%$ & \\
\hline Employment & -- & $1.8 \%$ & $1.6 \%$ & \\
\hline Population & -- & $1.6 \%$ & & \\
\hline
\end{tabular}

* Real GDP @ Factor Cost \$1997 Millions 


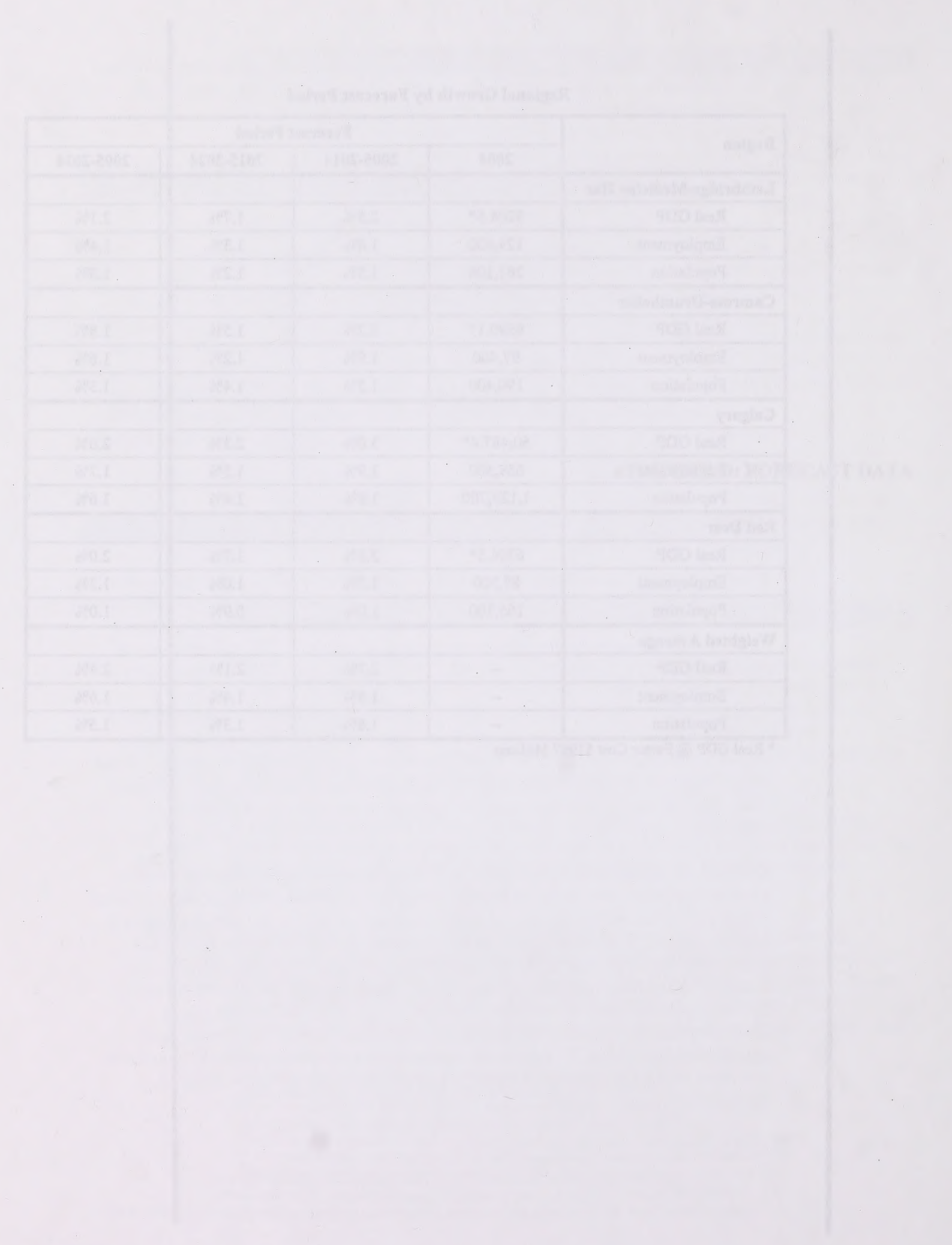



LIBRARY AND ARCHIVES CANADA

Bibliothèque et Archives Canada

I|||||||||||||||||||||||||||||||||||||||||||||||||||||||

33286538600871 